\title{
The WW II German Defences Structures around Ploumoguer (Finistère-FR)
}

\author{
Giancarlo T. Tomezzoli \\ Etno-Archaeological Observatory, Munich, Germany \\ Email: gt21949@gmx.de
}

How to cite this paper: Tomezzoli, G. T. (2018). The WW II German Defences Structures around Ploumoguer (Finistère-FR). Archaeological Discovery, 6, 62-87. https://doi.org/10.4236/ad.2018.62005

Received: January 15, 2018

Accepted: April 6, 2018

Published: April 9, 2018

Copyright $\odot 2018$ by author and Scientific Research Publishing Inc. This work is licensed under the Creative Commons Attribution International License (CC BY 4.0).

http://creativecommons.org/licenses/by/4.0/

\section{cc) (i) Open Access}

\begin{abstract}
Although the information about the German military presence in the sector of Ploumoguer (Finistère-FR) during the German Occupation of France (June 1940 - November 1944) is rather fragmentary, it resulted sufficient for identifying the most important military structures still present. They included the Stp (Stutzpunkt-Support Point) Re 80 at La Villeneuve-Suernevez, the Stp Re 311-FuMB 445 at Kervélédan, the Stp Re 77 at Kérigoarn-Kerizauen and the Stp Re 79 at Kergounan. The visits on the sites permitted to ascertain the preservations state of their Regelbauten (rule-built constructions) and verstärkten feldmäßigen Bauwerke (strengthened field constructions) (Vf). The role of the witnesses, already highlighted in previous publications, aided a lot also in this case for identifying and exploring components of said structures and so to complete the frame of the WWII German defence structures around Ploumoguer.
\end{abstract}

\section{Keywords}

WW II, Third Reich, Atlantic Wall, Ploumoguer, Stp Re 80, La Villeneuve, Stp Re 311, FuMB 445, Kervélédan, Stp Re 77, Kérigoarn, Stp Re 79, Kergounan, Finistère, France

\section{Introduction}

The information about the German military presence in the sector of Ploumoguer (Finistère-FR) during the German Occupation of France (June 1940 November 1944) is rather fragmentary, but sufficient for identifying the passage of some operative units and the most important military structures still present. These structures included the Stp (Stutzpunkt-Support Point) Re 80 at La Villeneuve-Suernevez, the Stp Re 311-FuMB 445 at Kervélédan, the Stp Re 77 at Kérigoarn-Kerizauen and the Stp Re 79 at Kergounan. They were formed both 
by Regelbauten (rule-built constructions) $(R)$ and verstärkten feldmäßigen Bauwerke (strengthened field constructions) ( $V f)$, some of them were already described in precedent publications (Tomezzoli, 2017a; Tomezzoli, 2017b).

\section{History}

The Wehrmacht 2d Group of the Artillery Regiment 343 (II. Gruppe Artillerie Regiment 343) was present in the sector of Ploumoguer from June 1943 to $\mathrm{Au}$ gust 1944, before to its retreat on the city of Brest. Its 6./A.R. 343 (Feldpost 44 $276 D$ ) operated the $S t p \operatorname{Re} 80$ at La Villeneuve-Suernevez, before its transfer to Le Conquet on July 1944. Its 5./A.R. 343 (Feldpost 44 276C) operated the Stp Re 77 at Kérigoarn-Kerizauen. Its 4./A.R. 343 operated the Stp Re 79 (Feldpost 44 $276 B)$ at Kergounan (or Kergonan), before its transfer on 21st January 1944 to Le Conquet (Floch, 2012) (Figure 1).

A detachment of the 1st Company of the 3rd Navy Radar Section (1. Kompanie 3. Marine-Funk-Meß-Abteilung) of the Kriegsmarine (Floch, 2012) operated the Stp Re 311-FuMB 445 radar observation station (FunkMess Beobachtung) Donau (Lippmann, 2016), indicated also as Stp Donau or Department (Dienststelle) Donau, at Kervélédan. On 14th January 1944, the Upper Radar Seaman and Support Point Leader (Ob. Fk. Matr. u. Stp.-Leiter) Hartelmeyer, justified the costs of the cart delivery of drink and kitchen water to the Stp Donau because the $1.5 \mathrm{~km}$ distance of the closest water point. The bill was countersigned by the Infantry Regiment Lieutenant and $1^{\text {st }}$ Company Chef (Oberleutnant R. I. u. 1. Komp. Chef). On 15th January 1944 the Corporal-Chief (Obergefreiter) Uhlig Fritz, 33 years old, was killed at the Stp during an air attack. The artillery battery protecting the Stp was involved in the France Liberation combats by bombarding, among other, the city of Saint-Renan. On 26th August 1944, the Stp 311 was attacked by the USAF. On 28th August 1944 it was conquered by the 2nd US Ranger and the F.F.I. (French Forces of the Interior) which killed 10 German soldiers and taken 89 prisoners on 10th September 1944 Ploumoguer was definitively freed (Floch, 2012).

\section{Stp Re 80}

The Stp Re 80, about $2 \mathrm{~km}$ far from Ploumoguer, comprised a heavy artillery battery formed by four $R 669$ and a $V f$ (Figures 2-7). Nowadays, they are located on a state property terrain, in a trench about $10 \mathrm{~m}$ wide and $1-2 \mathrm{~m}$ deep, perpendicular to the road Ploumoguer-Saint-Renan (Rapport Pinczon du Sel, 1947-1948).

The visits took place on 2nd January 2017 and 27th December 2017. The Stp Re 80 identified components were the following.

An $R 669$ (1) (48 $24^{\prime} 5.14^{\prime \prime} \mathrm{N}, 04^{\circ} 41^{\prime} 52.98^{\prime \prime} \mathrm{W}, 97.7 \mathrm{~m}$ ) (Figure 4) for 100 or $150 \mathrm{~mm}$ gun (Rapport Pinczon du Sel, 1947-1948). It presented a well preserved concrete structure partially covered by vegetation, without damages due to bombardments or combats. The rear aperture, partially obstructed by vegetation, introduced into the fire room deprived of its original furniture. On the floor, 


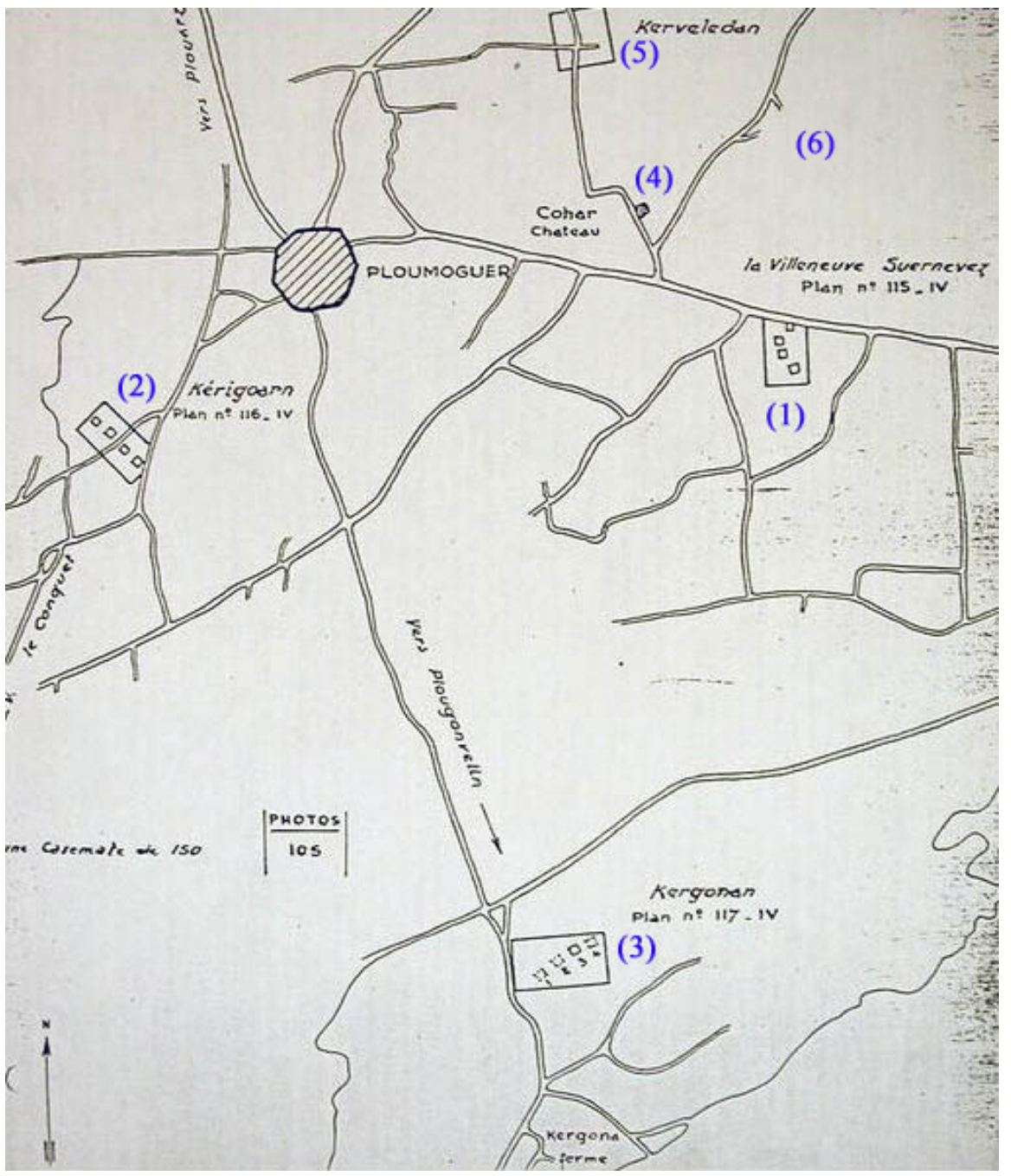

Figure 1. German defence structures around Plumoguer: (1) Stp Re 80 at La Villeneuve-Suernevez; (2) Stp Re 77 at Kérigoarn-Kerizauen; (3) Stp Re 79 at Kergounan; (4) manor of Cohars; (5) Stp Re 311-FuMB 445 Donau at Kervélédan; (6) Possible German transmission centre at Penhars (Rapport Pinczon du Sel, 1947-1948, Plan_no. 114-IV).

the square carriage wheel gun emplacement and the arcuate gun carrier legs emplacement, observed in other $R$ 669s (Tomezzoli \& Pottier, 2016), although both covered by terrain, were well recognizable. The walls preserved the original white painting and the vertical wood insulation supports embedded in the concrete. On the walls, no traces of a thermal insulation system. The metallic ceiling preserved two gun lifting joints and the gates of the combat gas extraction system, deprived of their original grids. The ammunition room was empty and the combat gas extraction system room preserved some rusted portion of conduits. The exhausted combat gas pipe and a possible niche hosting it (Tomezzoli \& Pottier, 2016), on the $R 699$ (1) rear side, were covered by vegetation and not visible.

An $R 669(2)\left(48^{\circ} 24^{\prime} 3.96^{\prime \prime} \mathrm{N}, 04^{\circ} 41^{\prime} 53.83^{\prime \prime} \mathrm{W}, 97.76 \mathrm{~m}\right)$ (Figure 5) for 100 or $150 \mathrm{~mm}$ gun. Its concrete structure was covered by vegetation, but apparently 


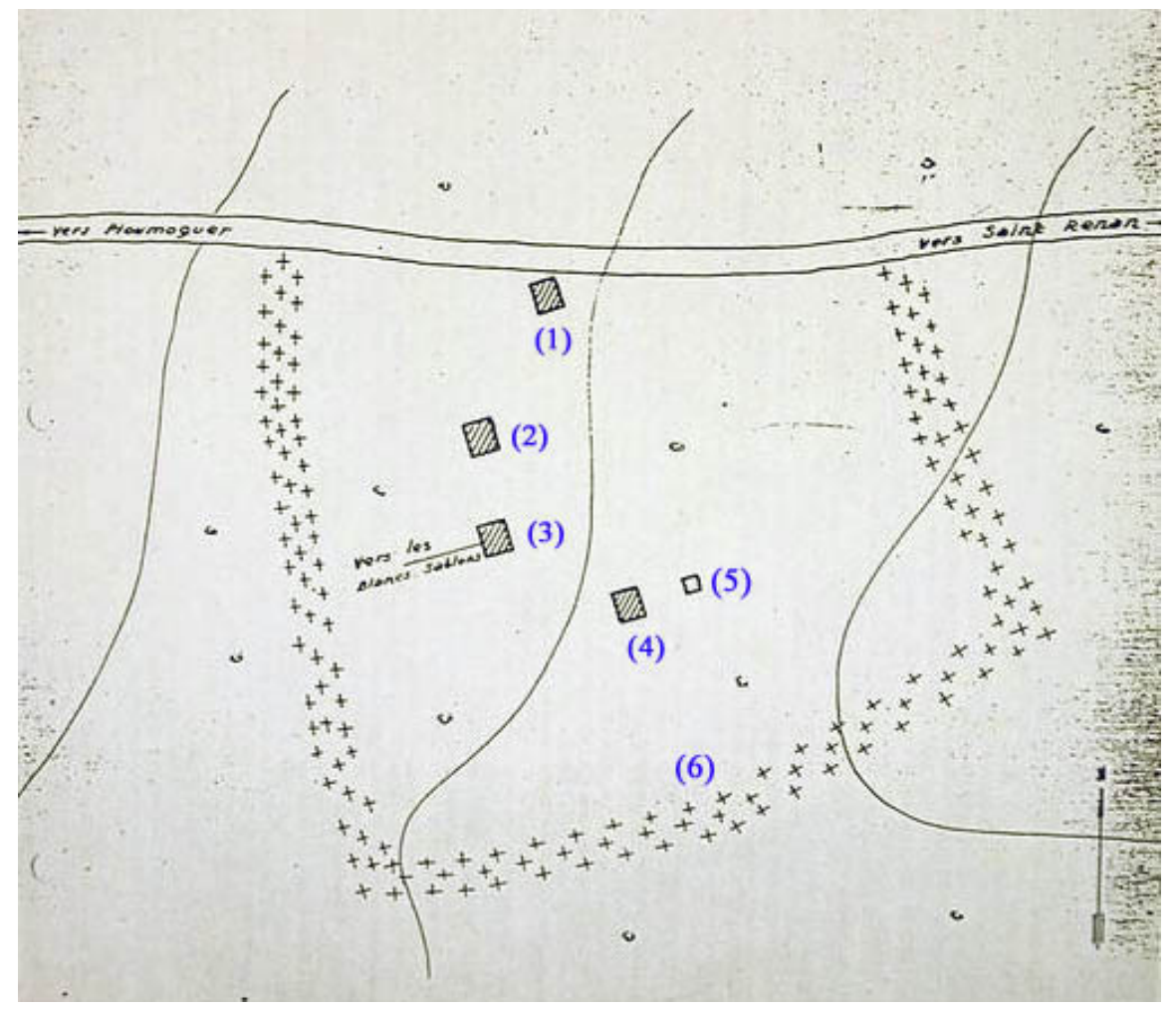

Figure 2. Stp Re 80: (1) $R$ 669, (2) $R$ 669, (3) $R$ 669, (4) $R$ 669, (5) Vf, (6) barriers and mine fields (Rapport Pinczon du Sel, 1947-1948, Plan_no. 115-IV).

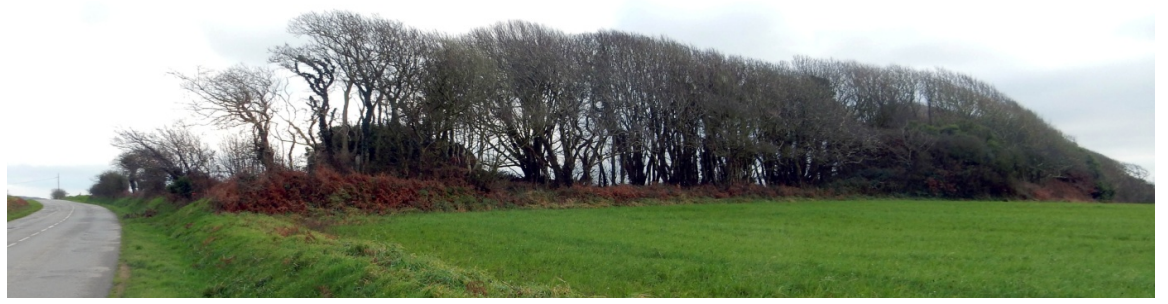

Figure 3. Stp Re 80: general view, on the left road to Ploumoguer, through the vegetation $R 669(1)$.

without damages due to bombardments or combats. The rear aperture introduced into the fire room fully occupied by used tires. The walls preserved the original white painting. The metallic ceiling preserved two joints for the gun lifting and the gates of the combat gas extraction system deprived of their original grids. The ammunition room was empty and the combat gas extraction system room preserved some rusted portion of conduits. The exhausted combat gas pipe and a possible niche hosting it, on the R 699 (2) rear side, were covered by vegetation and not visible.

An $R 669$ (3) $\left(48^{\circ} 24^{\prime} 3.08^{\prime \prime} \mathrm{N}, 04^{\circ} 41^{\prime} 52.75^{\prime \prime} \mathrm{W}, 97.13 \mathrm{~m}\right)$ (Figure 6) for 100 or $150 \mathrm{~mm}$ gun. Its concrete structure was covered by vegetation, but apparently without damages due to bombardments or combats. The rear aperture introduced 


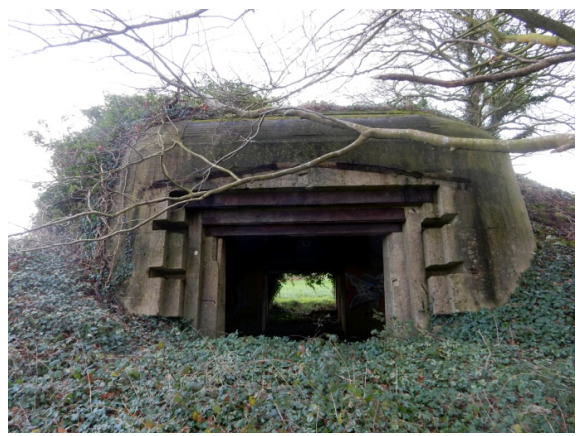

(a)

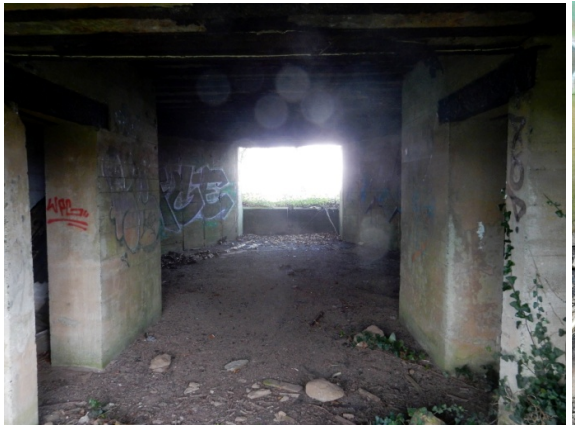

(c)

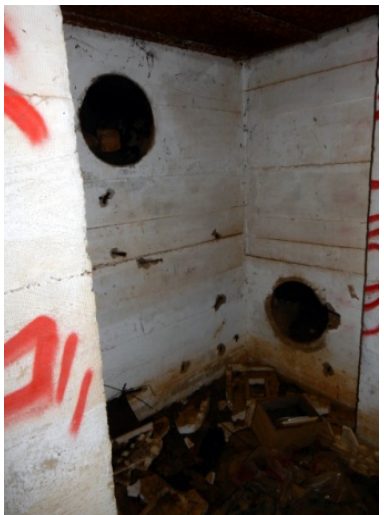

(e)

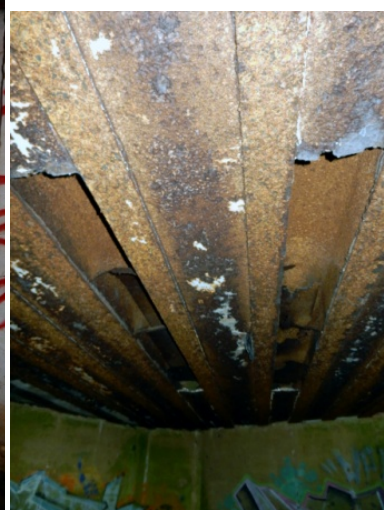

(f)

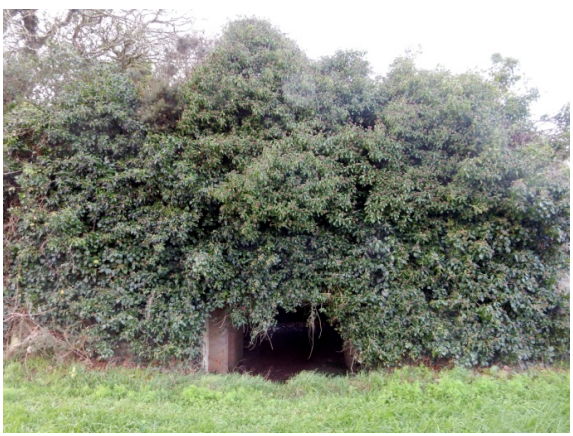

(b)

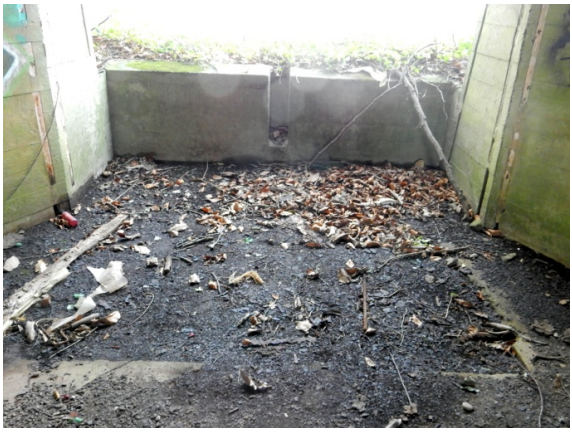

(d)

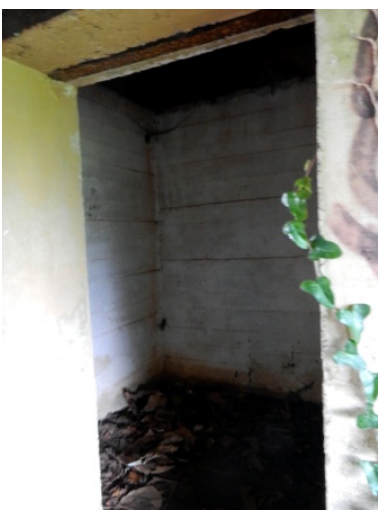

(g)

Figure 4. Stp Re 80-R 669 (1): (a) Fire room front side aperture with splinter guards; (b) Fire room rear side aperture partially covered by vegetation; (c) Fire room, on the left side, entrance of the combat gas extraction system room, on the right side entrance of the ammunition room; (d) Fire room front side aperture and square carriage wheel gun emplacement; (e) Combat gas extraction system room; (f) Fire room, metal ceiling with gates of the combat gas extraction system; (g) Ammunition room.

into the fire room deprived of its original furniture. The walls preserved the original white painting, somewhere covered by contemporary graffiti, and the vertical wood insulation supports embedded in the concrete. On the walls, no traces of a thermal insulation system. On the floor, the square carriage wheel gun emplacement and the arcuate gun carrier legs emplacement, although both covered by terrain, were well recognizable. The metallic ceiling preserved two gun lifting joints and the gates of the combat gas extraction system, deprived of 


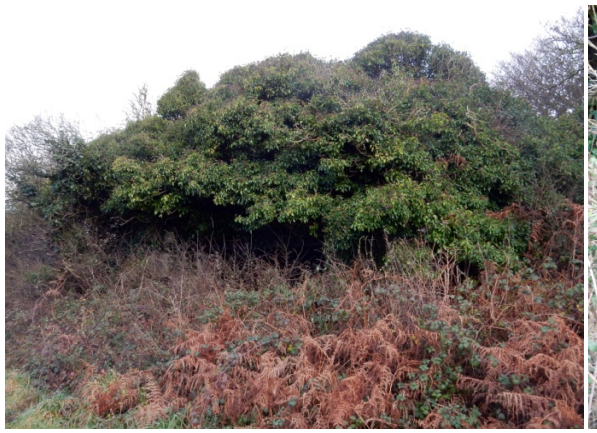

(a)

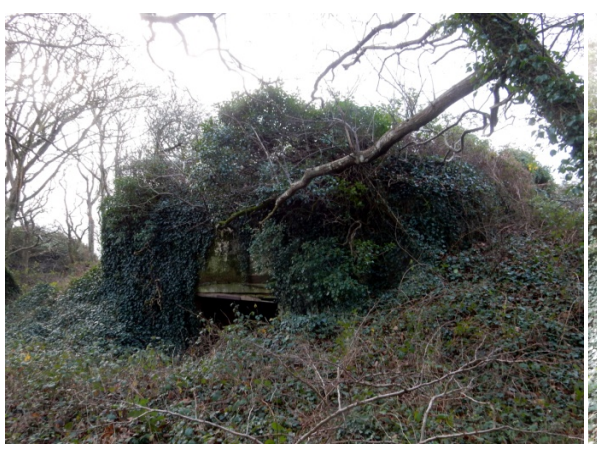

(c)

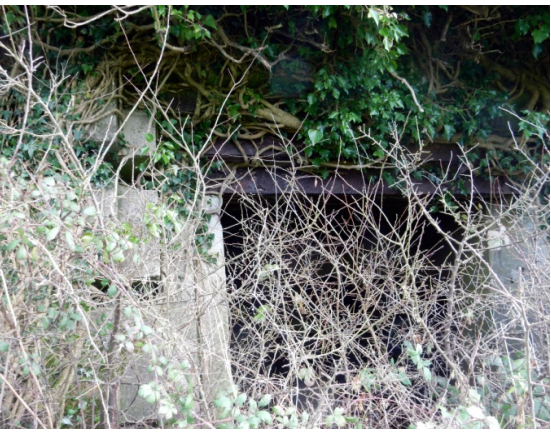

(b)

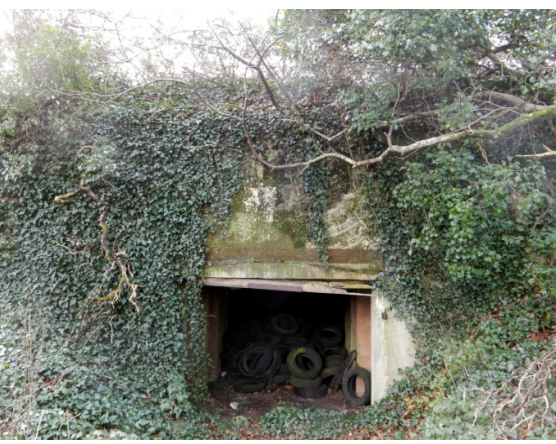

(d)

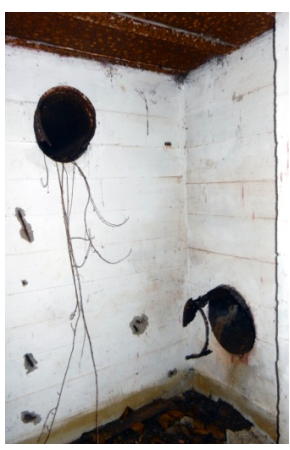

(e)

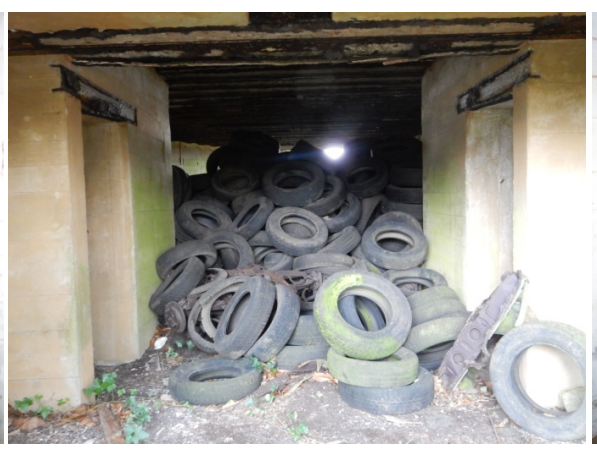

(f)

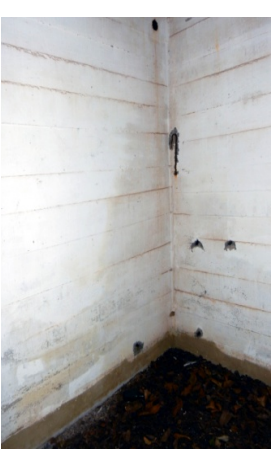

(g)

Figure 5. Stp $\operatorname{Re} 80-R 669$ (2): (a) Front side covered by vegetation; (b) Fire room front aperture; (c) Rear side covered by vegetation; (d) Fire room rear side aperture; (e) Combat gas extraction system room; (f) Fire room, on the left side entrance of the combat gas extraction system room, on the right entrance of the ammunition room; (g) Ammunition room.

their original grids. The walls of the ammunition room were covered by contemporary graffiti. The combat gas extraction system room preserved some rusted portion of conduits. The exhausted combat gas pipe and a possible niche hosting it, on the $R 699$ (3) rear side, were covered by vegetation and not visible.

On the ground, near the $R 699$ (3) rear side, a small bore $30 \times 30 \mathrm{~cm}$, betrayed the existence of the trench drainage system.

An $R 669$ (4) $\left(48^{\circ} 24^{\prime} 2.26^{\prime \prime} \mathrm{N}, 04^{\circ} 41^{\prime} 53.14^{\prime \prime} \mathrm{W}, 95.89 \mathrm{~m}\right)$ (Figure 7) for 100 or $150 \mathrm{~mm}$ gun. Its concrete structure was covered by vegetation, but apparently without damages due to bombardments or combats. The rear aperture introduced into the fire room, deprived of its original furniture. The walls preserved 
the original white painting, covered by contemporary graffiti, and the vertical wood insulation supports embedded in the concrete. On the walls, no traces of a

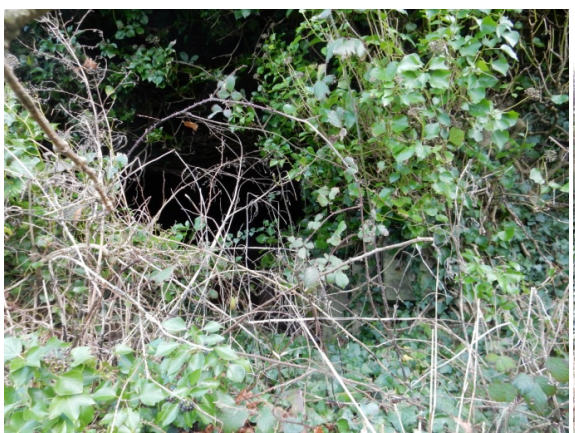

(a)

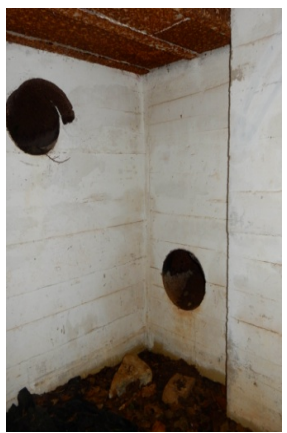

(c)

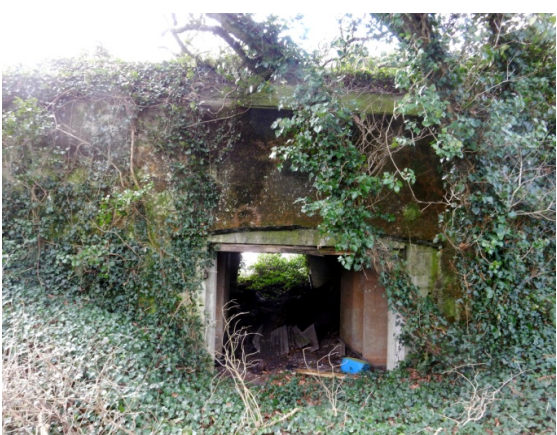

(b)

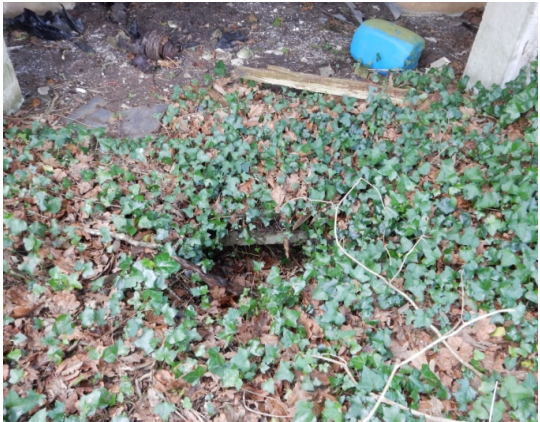

(e)

Figure 6. Stp $\operatorname{Re} 80-\operatorname{Re} 669$ (3): (a) Fire room front side aperture covered by vegetation; (b) Fire room rear side aperture; (c) Combat gas extraction system room; (d) Ammunition room, on the floor, abandoned, a washing machine drum; (e) Trench floor, bore of the drainage system.

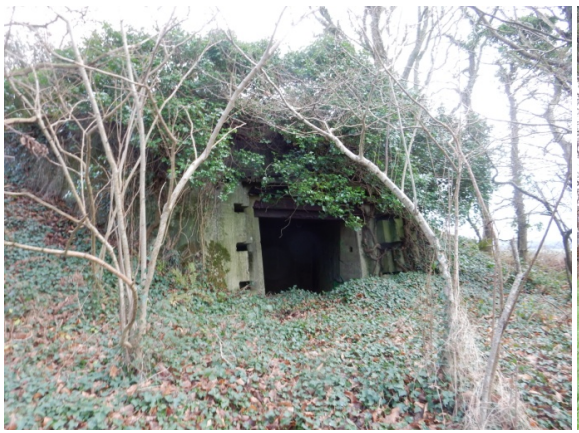

(a)

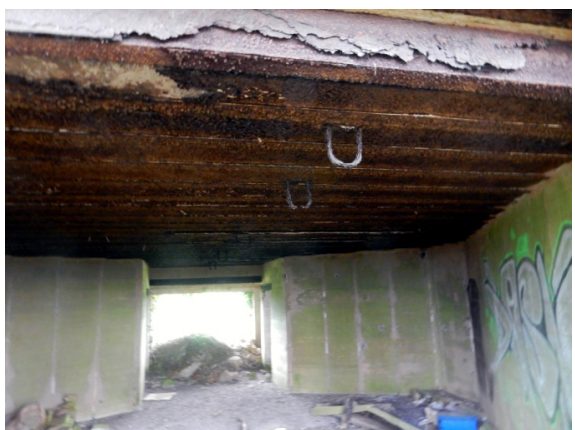

(c)

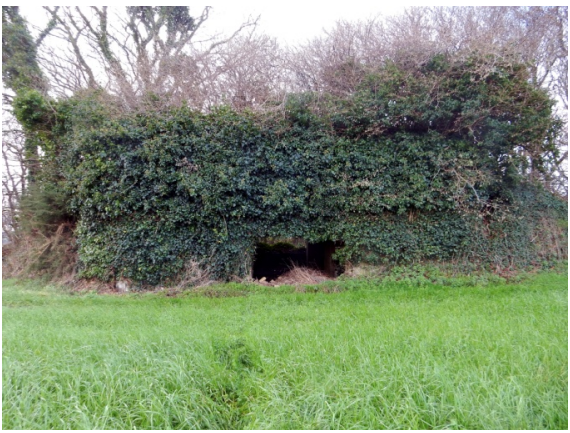

(b)

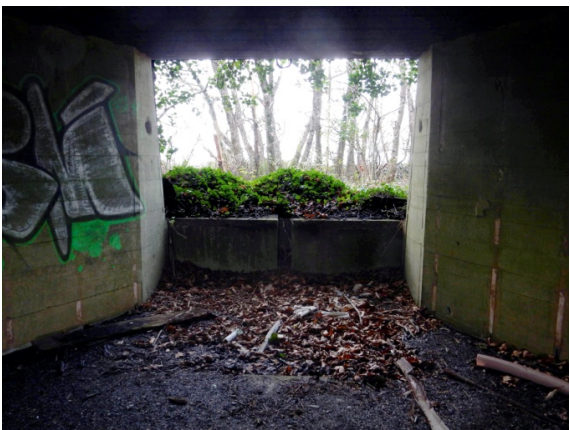

(d) 


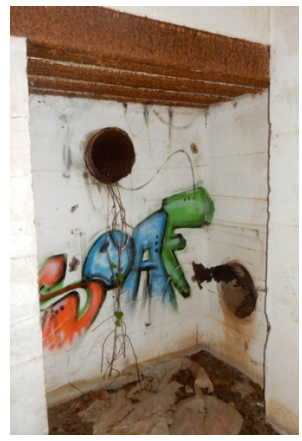

(e)

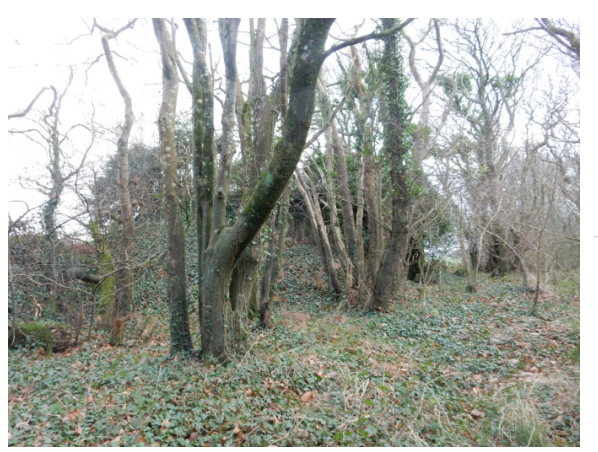

(i)

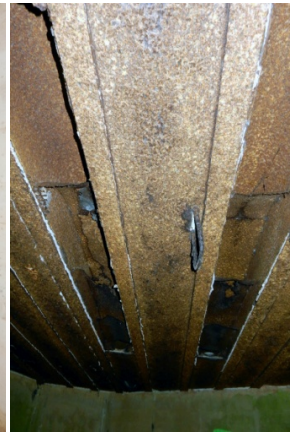

(f)

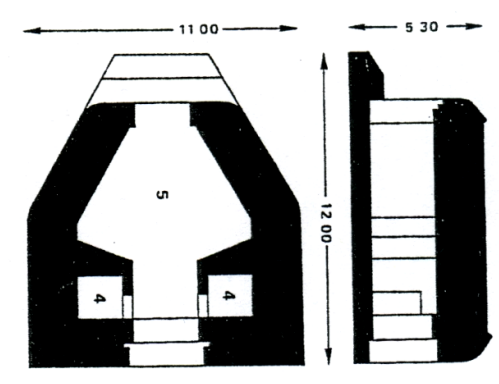

(j)

Figure 7. Stp Re 80-Re 669 (4): (a) Fire room front side aperture with splinter guards; (b) Fire room rear side aperture; (c) Fire room, metallic ceiling with two gun lifting joints and vertical wood insulation supports embedded in the wall concrete; (d) Fire room, square carriage wheel gun emplacement, (e) Combat gas extraction system room; (f)-(g) Metallic ceiling with joint for the gun lifting and gates of the combat gas extraction system; (h) Ammunition room; (i) Trench; (j) $R 669$ plan: 4 ammunition room, 5 fire room (Rudi, 1998).

thermal insulation system. On the floor, the square carriage wheel gun emplacement and the arcuate gun carrier legs emplacement, although both covered by terrain, were well recognizable. The metallic ceiling preserved two gun lifting joints and the gates of the combat gas extraction system, deprived of their original grids. The ammunition room was empty. The walls of the combat gas extraction system room were covered by contemporary graffiti and preserved some rusted portion of conduits. The exhausted combat gas pipe and a possible niche hosting it, on the $R 699$ (4) rear side, was covered by vegetation and not visible.

The search on the terrain for the $V f(5)$ and rests of other constructions like ammunition bunkers, storage bunkers, anti-aircraft guns bunkers and lodging barracks provided no result as confirmed also by Figure 2. The search on the terrain for metallic barriers, barbed wires and mine fields encircling Stp Re 80 (Figure 2) provided no results.

\section{Stp Re 311-FuMB 445 Donau}

The Stp Re 311-FuMB 445 Donau (Lippmann, 2016), about $1.3 \mathrm{~km}$ far from Ploumoguer was already mentioned in a previous publication (Tomezzoli, 2017c). Together with its associated FuMB 686 Wolga on the Menez-Hom hill, 
they were probably the first two radar emission observation stations (FuMB-Funk Mess Beobachtung) installed in Brittany for detecting foe radar emissions and remained the only two up to the end of 1943. All the information collected were centralized at Donau and directly transmitted to the Commander-in-Chief of Naval Group West (Oberbefehlshaber des Marinegruppenkommando West) based in Paris, without passing through the Kriegsmarine centre of Nostang as the other radar stations, to be diffused, if necessary and on reserved frequencies, to the concerned unities. A FuMB net was developed later on 1944 comprising up to about thirty FuMBs installed on the Atlantic and Mediterranean coasts. In Brittany said $F u M B$ net comprised, in addition to the two mentioned $F u M B$, also the $F u M B$ s of Brignogan, Perros-Guirec, Erquy, Trévignon and Belle Île, all connected by telephone to each other and to the $F u M B$ coordination center in Plumoguer (Blanchard, 2017; Dupont et al., 2007). The FuMB 445 was serviced by parts of the $1^{\text {st }}$ Company of the $3^{\text {rd }}$ Radar Section (1./3. FuMAbt-Funk Mess Abteilung) (Lippmann, 2016).

It was by chance that the Stp Re 311-FuMB 445 site and a possible German transmission center site were discovered. Arrived on 2nd January 2017 at a farm near Kérigoarn-Kerizauen, at my question about the presence of a German radar (Lippmann, 2016) during the WW II, the proprietor confirmed that a German radar (Figure 8) at Kervélédan, $1.2 \mathrm{~km}$ from Ploumoguer, was active during the period of the German Occupation. He kindly offered himself as guide for arriving to the Stp site. Difficult to be reached and to be recognized in a dense

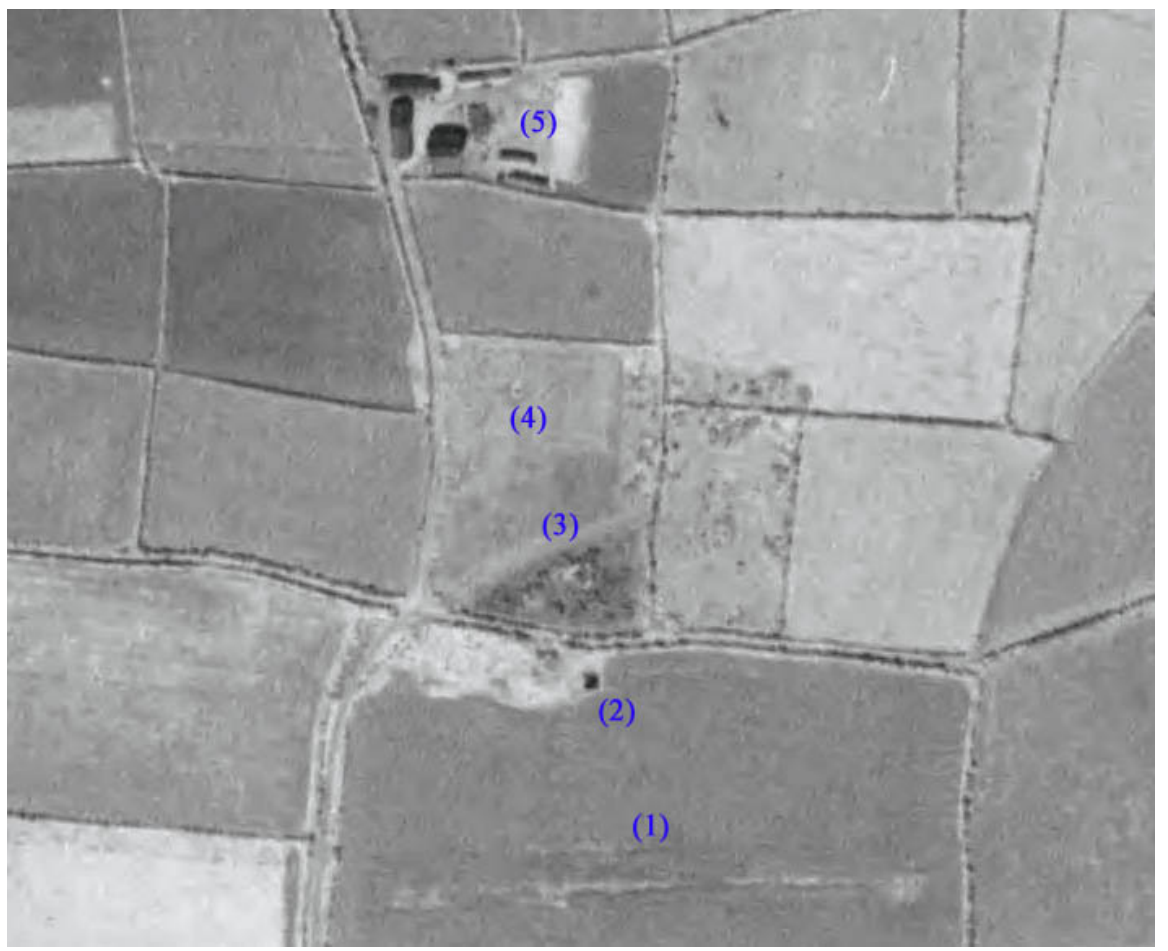

Figure 8. Stp Re 311-FuMB 445: (1) possible anti-tank trenches; (2) V 256; (3) possible defense constructions; (4) cylindrical water pit of German construction; (5) Kervélédan farm (C0417-0103_1961_F0317-0717_0068, nº 68, Échelle 1/25632, Argentique, 29/06/1961). 
wood near a modern water reservoir, a bunker $\left(48^{\circ} 24^{\prime} 38.07^{\prime \prime} \mathrm{N}, 04^{\circ} 42^{\prime} 33.81^{\prime \prime} \mathrm{W}\right.$, $122.04 \mathrm{~m}$ ), about $10 \times 10 \mathrm{~m}$, was buried in the terrain and covered by vegetation (Figure 9). Apparently, its concrete structure was in a good preservation

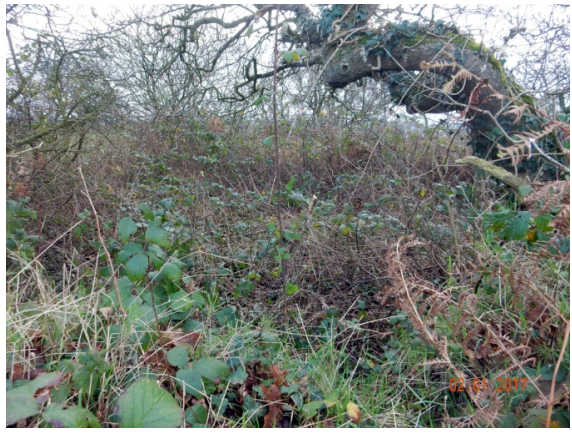

(a)

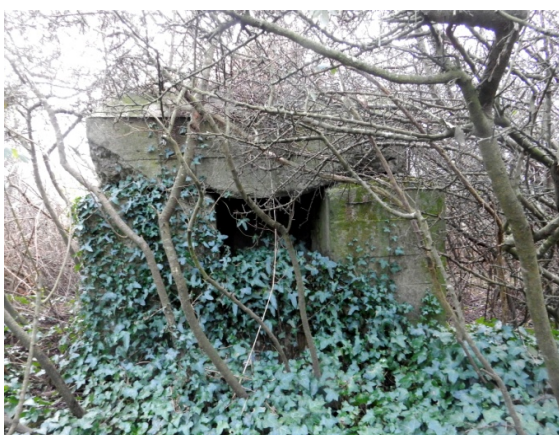

(c)

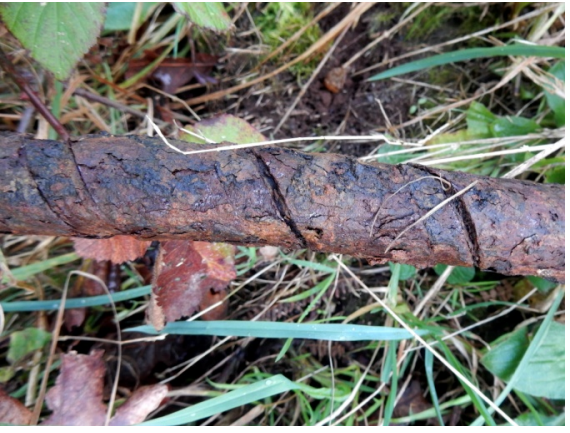

(b)

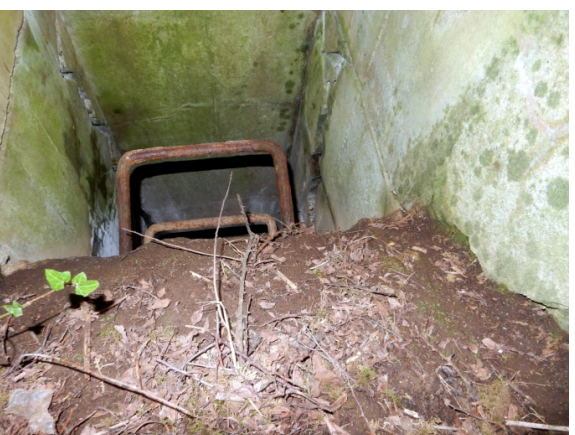

(d)

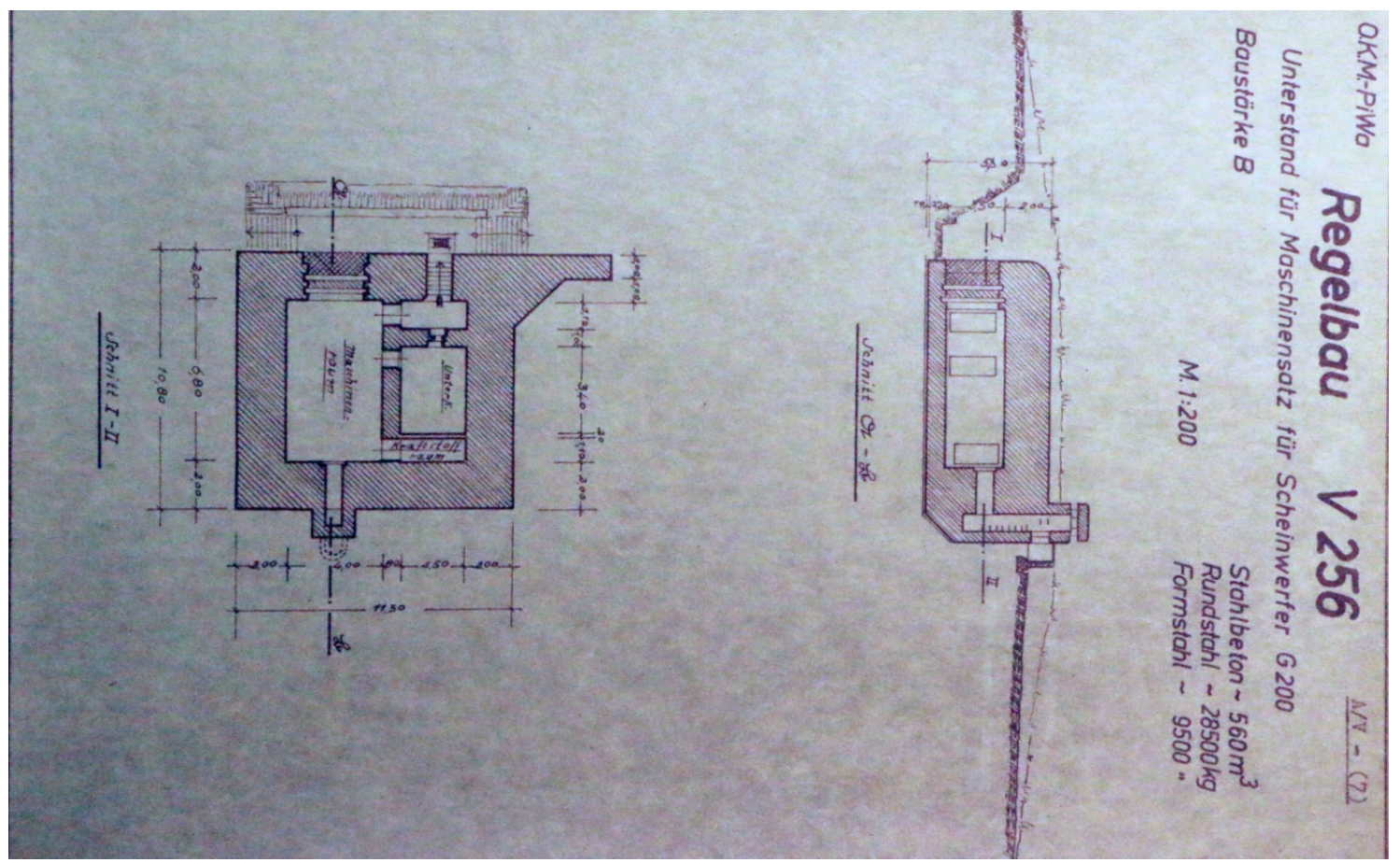

(e)

Figure 9. Stp Re 311-FuMB 445: (a) Wood near Kervélédan; (b) Mobile cable in the wood; (c) V 256; partially deformed emergency exit; (d) V 256, vertical stair; (e) V 256 plan: lodgment (Unterk), machine room (Machinen-raum), fuel depot room (Kraftstoff-raum) (BAMA, 1944). 
state, because no relevant damages due to bombardments or combats were remarked. Only its emergency exit protruding from the terrain, covered by a concrete slab $50 \mathrm{~cm}$ thick and provided with an internal, vertical metal stair was slightly deformed. However, said emergency exit elements were sufficient for identifying the bunker as a $V 256$ (Figure 9(e)), a machine bunker for a searchlight $G$ 200. Dissuaded from descending inside the bunker, its interior still attends to be inspected. The proprietor indicated, near the $V 256$, a cylindrical water pit $\left(48^{\circ} 24^{\prime} 41.42^{\prime \prime} \mathrm{N}, 04^{\circ} 42^{\prime} 35.68^{\prime \prime} \mathrm{W}, 123.83 \mathrm{~m}\right)$ of German construction (Figure 10).

The proprietor further indicated, not far from the $V 256$, in a cultivated field $\left(48^{\circ} 24^{\prime} 44.07^{\prime \prime} \mathrm{N}, 04^{\circ} 41^{\prime} 43.56^{\prime \prime} \mathrm{W}, 126.01 \mathrm{~m}\right)$ near a farm at Penhars (Figure 1), about $2.26 \mathrm{~km}$ from Ploumoguer, a possible German transmission center site formed by a small bunker and several antennae. The visit of the field took place on 27th December 2017. At my question about the presence of a German transmission center, the Penhars farm proprietor declared that his father and he cultivated the fields around the farm from the after war, and on the fields there were no construction of the German Occupation period. The supposed small bunker was a $5 \times 5 \mathrm{~m}$ livestock forage depot and supposed antenna supports were livestock troughs.

\section{Stp Re 77}

The Stp Re 77, about $1 \mathrm{~km}$ from Ploumoguer, comprised a heavy artillery battery formed by four $R 669$ and several $V f$ (Figures 11-20). Nowadays, they are located on a private terrain, at the junction of the roads Ploumoguer-Le Conquet, Plumoguer-Blanc Sablons (Rapport Pinczon du Sel, 1947-1948). The proprietor allowed the access to the site without problems. The visits took place on 2nd January 2017 and 27th December 2017. The Stp Re 77 identified components were the following.

An $R 669(1)\left(48^{\circ} 23^{\prime} 46.1^{\prime \prime} \mathrm{N}, 04^{\circ} 43^{\prime} 55.05^{\prime \prime} \mathrm{W}, 48.37 \mathrm{~m}\right.$ ) (Figure 12) for $150 \mathrm{~mm}$ gun. Its concrete structure was covered by vegetation, but apparently without damages due to bombardments or combats. The rear aperture introduced into

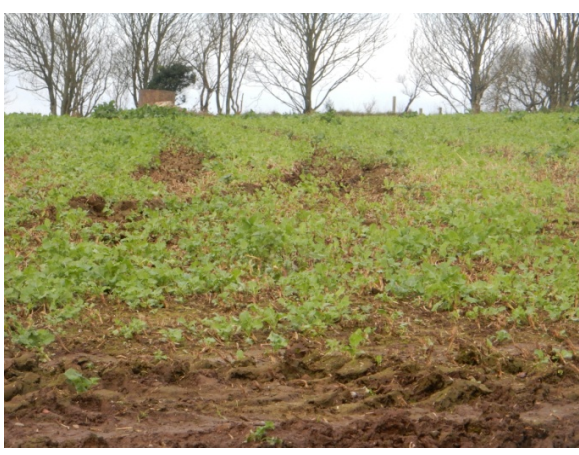

(a)

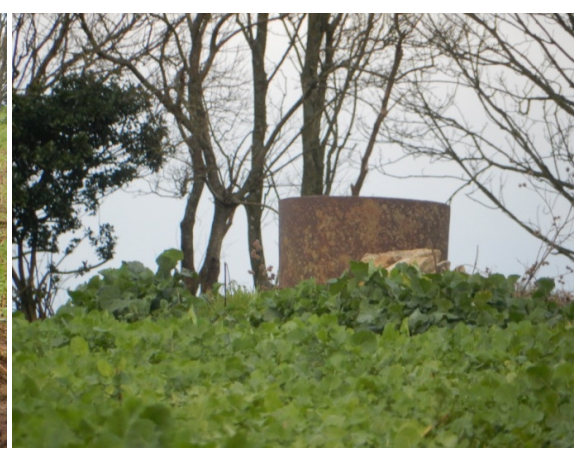

(b)

Figure 10. Stp Re 311-FuMB 445: (a) Field near V 256; on the upper left cylindrical water pit of German construction; (b) Cylindrical water pit. 


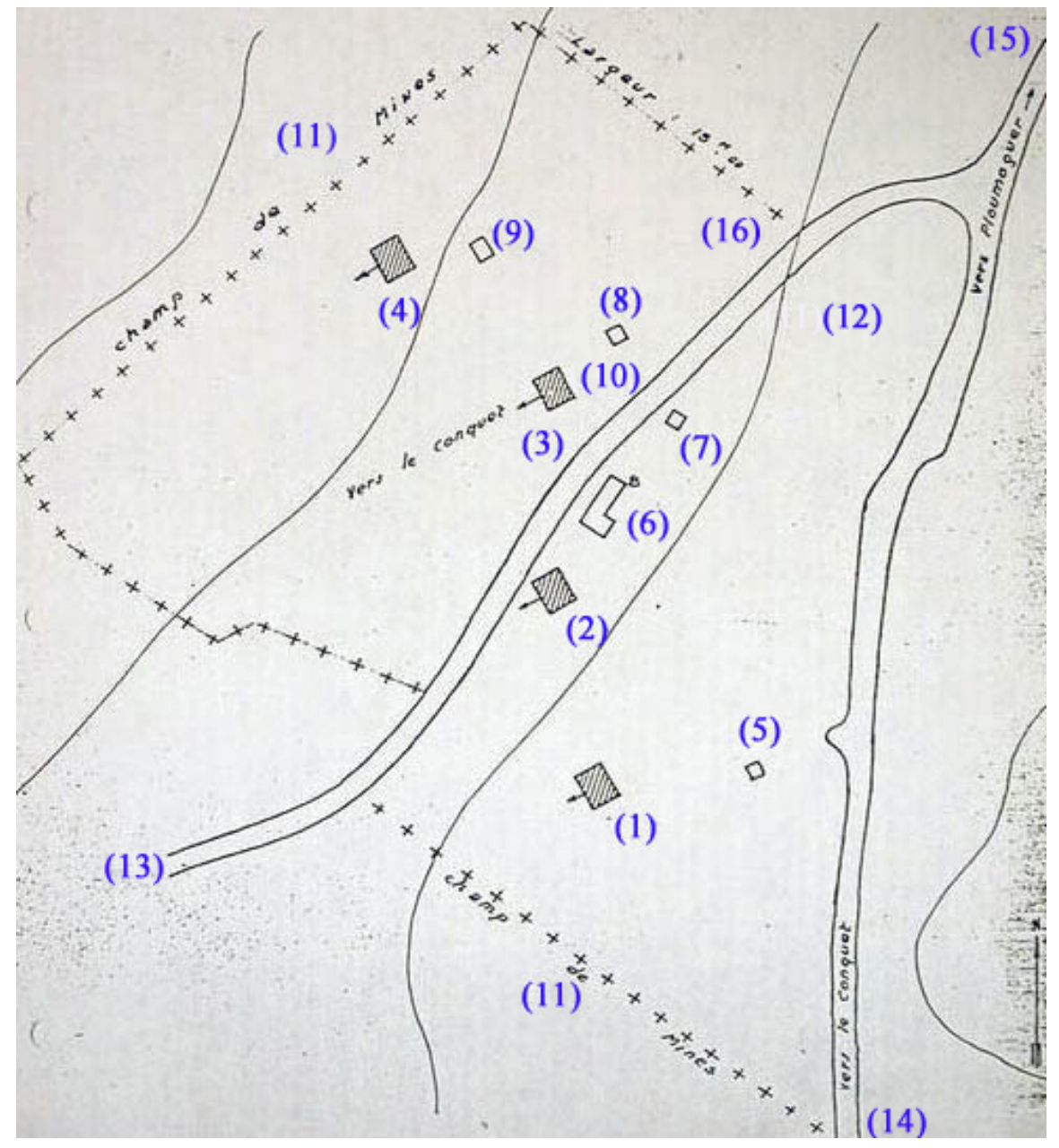

Figure 11. Stp Re 77: (1) $R$ 669; (2) $R$ 669; (3) $R$ 669; (4) $R$ 669; (5)-(10) Vf; (11) barriers and mine fields; (12) Vf; (13) road to Blanc Sablons; (14) road to Le Conquet; (15) road to Ploumoguer; (16) Vf (Rapport Pinczon du Sel, 1947-1948, Plan_no. 116-IV).

an empty fire room, deprived of its original furniture. The walls preserved the original white painting and the vertical wood insulation supports embedded in the concrete. On the walls, no traces of a thermal insulation system. On the floor, the square carriage wheel gun emplacement and the arcuate gun carrier legs emplacement, although both covered by terrain, were well recognizable. The metallic ceiling preserved five joints for the gun lifting and the gates of the combat gas extraction system, deprived of their original grids. The ammunition room was empty and the combat gas extraction system room preserved some rusted portion of conduits. The exhausted combat gas pipe and a possible niche hosting it, on the $R 699$ (3) rear side, were covered by vegetation and not visible.

A $V f(12)\left(48^{\circ} 23^{\prime} 46.15^{\prime \prime N}, 04^{\circ} 43^{\prime} 52.08^{\prime \prime} \mathrm{W}, 49.33 \mathrm{~m}\right.$ ) (Figure $13(\mathrm{a})$ ), about $8 \times$ $4 \mathrm{~m}$, completely buried in the terrain. Only its coverage emerged from the terrain. The entrance was obstructed by the terrain; so that the inspection of the interior was not possible. The apparent absence on its coverage of chimney conduits suggested that it was intended for storing ammunitions and/or 


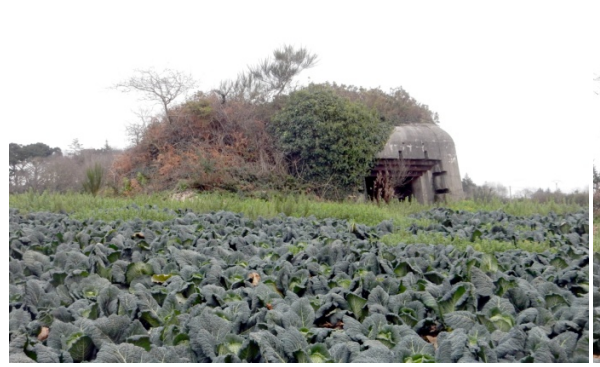

(a)

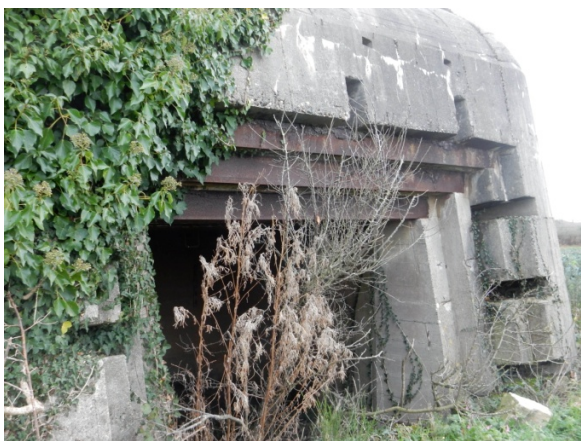

(c)

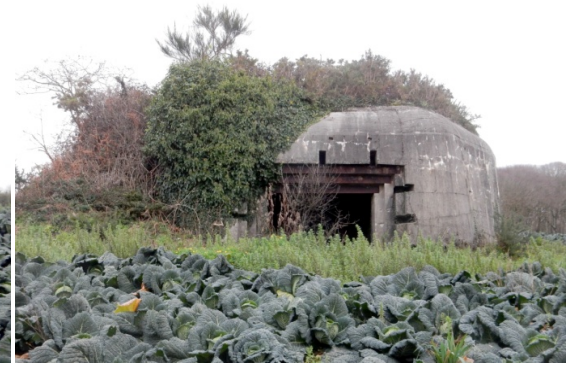

(b)

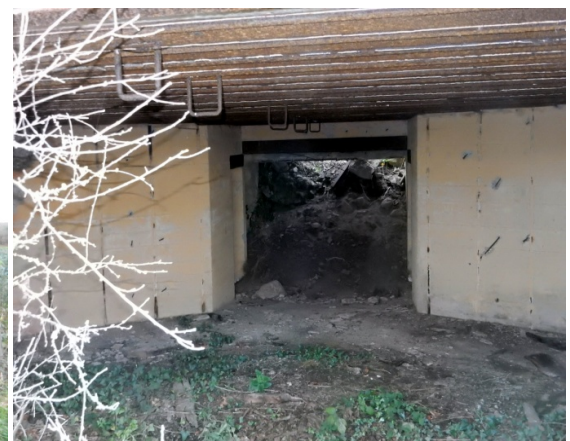

(d)

Figure 12. Stp Re 77-R 669 (1): (a)-(c) Fire room front side aperture with splinter guards; (d) Fire room, on the left side, entrance of the ammunition room, on the right side entrance of the combat gas extraction system room, on the walls the original white painting and the vertical wood insulation supports embedded in the concrete, on the floor, the arcuate gun carrier legs emplacement, on the metallic ceiling the five gun lifting joints.

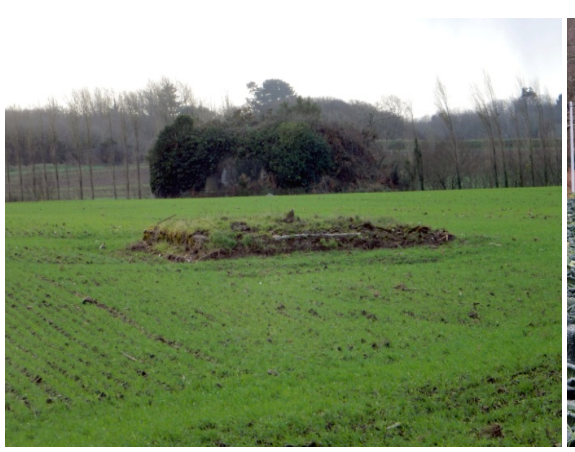

(a)

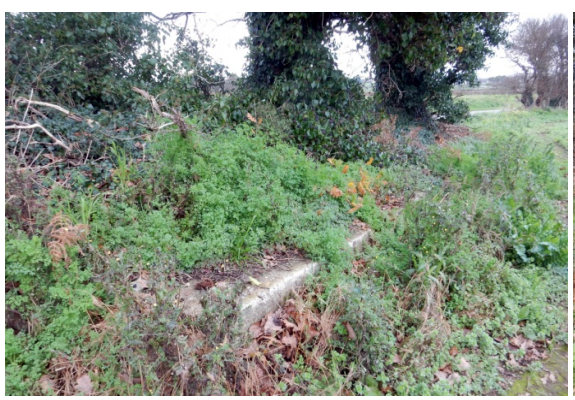

(c)

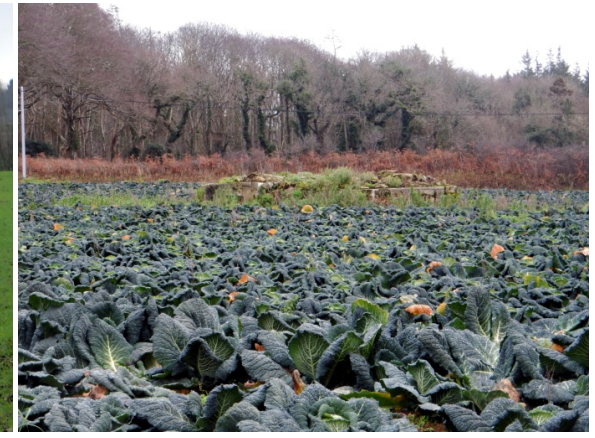

(b)

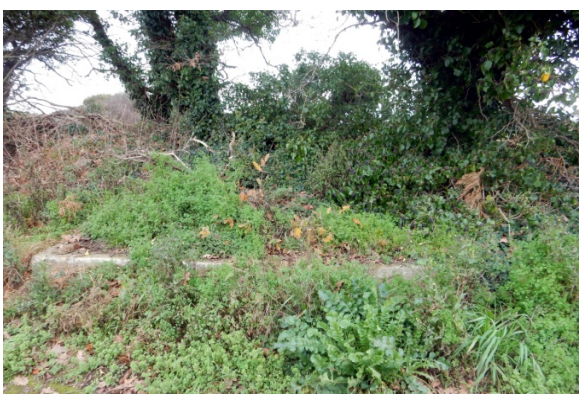

(d)

Figure 13. Stp Re 77: (a) $V f(12)$, in the foreground $R 669$ (1); (b) $V f(5)$, seen from $R 669$ (1); (c) $V f(7)$ side view; (d) $V f(7)$ front view. 
materials, although the function of guardhouse for a group of soldiers, at the one entrance of the Stp, cannot be excluded. The emerging $V f(12)$ concrete structure was in a good preservation state without damages due to bombardments or combats.

A $V f(5)\left(48^{\circ} 23^{\prime} 46.15^{\prime \prime N}, 04^{\circ} 43^{\prime} 52.08^{\prime \prime} \mathrm{W}, 49.33 \mathrm{~m}\right.$ ) (Figure $13(\mathrm{~b})$ ), about $6 \times$ $4.50 \mathrm{~m}$, emerged about one meter from the terrain. It was provided with one entrance not provided with protection walls. The entrance was obstructed by terrain and vegetation; so that the inspection of the interior was not possible. The apparent absence on its coverage of chimney conduits and its position, about 50 $\mathrm{m}$ from the $R 669$ (1), suggested that it was intended for storing ammunition and/or materials for the $R 669$ (1) rather than hosting a group of soldiers. The emerging Vf (5) concrete structure was in a good preservation state without damages due to bombardments or combats.

A $V f(7)\left(48^{\circ} 23^{\prime} 50.48^{\prime \prime} \mathrm{N}, 04^{\circ} 43^{\prime} 52.42^{\prime \prime} \mathrm{W}, 50.72 \mathrm{~m}\right)$ (Figures $13(\mathrm{c})$-(d)), similar to $V f(5)$ was completely buried in the terrain. The entrance was obstructed by the terrain; so that the inspection of the interior was not possible. The apparent absence on its coverage of chimney conduits and its position, about $60 \mathrm{~m}$ from the $R 669$ (2), suggested that it was intended for storing ammunition and/or materials for the $R 669$ (2) rather than hosting a group of soldiers. The emerging $V f(7)$ concrete structure was in a good preservation state without damages due to bombardments or combats.

A $V f(6)\left(48^{\circ} 23^{\prime} 49.29^{\prime \prime} \mathrm{N}, 04^{\circ} 43^{\prime} 54.82^{\prime \prime} \mathrm{W}, 49.77 \mathrm{~m}\right)$ (Figure 14), about $30 \mathrm{~m}$ from $R 669$ (2), indicated by the proprietor, was completely buried in the terrain. The labyrinth entrance, free from obstructions, given access to an internal corridor having a rectangular niche about $60 \times 50 \times 40 \mathrm{~cm}$ on each side. The corridor was connected with the entrance of an interior single room about $6 \times 6 \mathrm{~m}$ large without metallic ceiling. The room preserved on one wall the access to an emergency exit. The corridor and the room preserved their original white painting, although a grey unfinished attempt of painting was visible in the room. The $V f(6)$ concrete structure was in a good preservation state without damages due to bombardments or combats.

An $R 669$ (2) $\left(48^{\circ} 23^{\prime} 48.35^{\prime \prime} \mathrm{N}, 04^{\circ} 43^{\prime} 55.33^{\prime \prime} \mathrm{W}, 50.28 \mathrm{~m}\right.$ ) (Figure 15) for 150 $\mathrm{mm}$ gun. Its concrete structure was covered by vegetation, but apparently without damages due to bombardments or combats. The rear aperture introduced into an empty fire room, deprived of its original furniture. The walls preserved the original white painting and the vertical wood insulation supports embedded in the concrete. On the walls, no traces of a thermal insulation system. On the floor, the square carriage wheel gun emplacement and the arcuate gun carrier legs emplacement, although both covered by terrain, were well recognizable. The metallic ceiling preserved two joints for the gun lifting and the gates of the combat gas extraction system, deprived of their original grids. The ammunition room was empty and the combat gas extraction system room preserved some rusted portion of conduits. The exhausted combat gas pipe and a possible niche hosting it, on the $R 699$ (2) rear side, were covered by vegetation and not visible. 


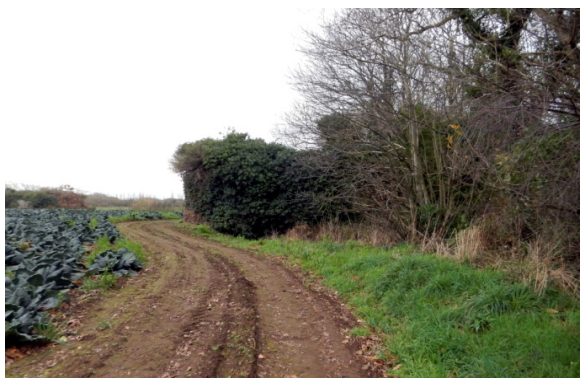

(a)

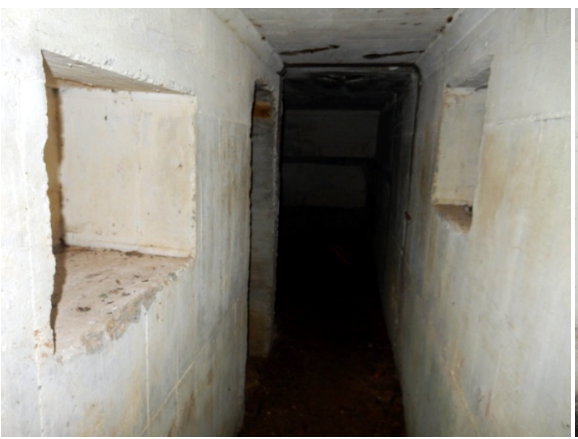

(c)

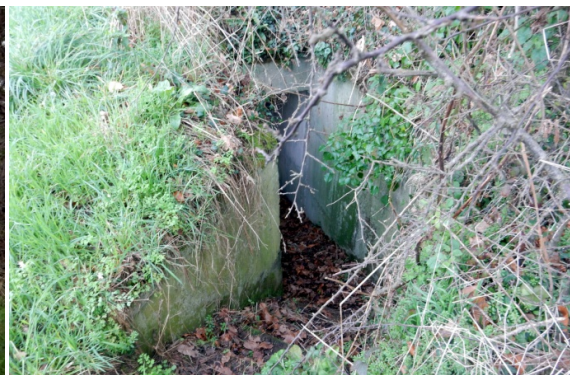

(b)

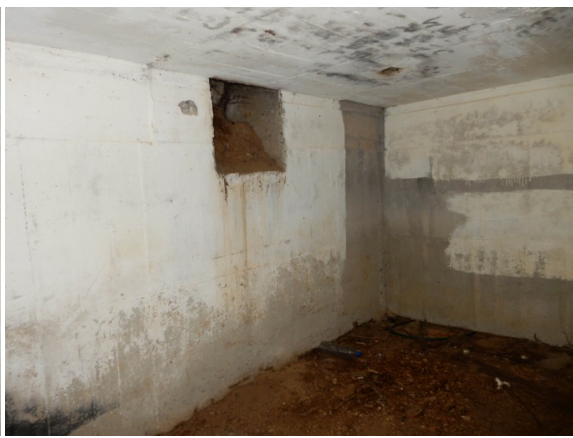

(d)

Figure 14. Stp Re 77-Vf(6): (a) Access road; (b) Labyrinth entrance, (c) Internal corridor with niches, (d) Internal room with emergency exit.

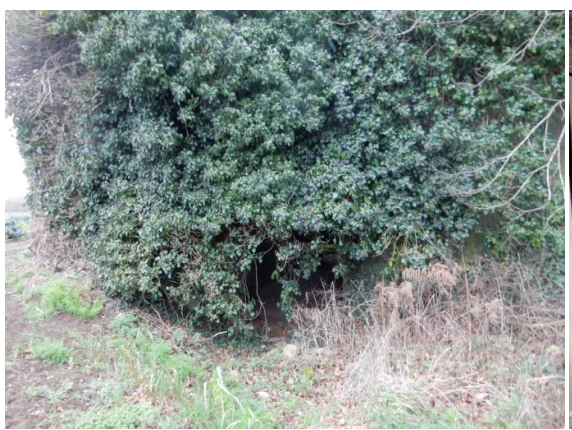

(a)

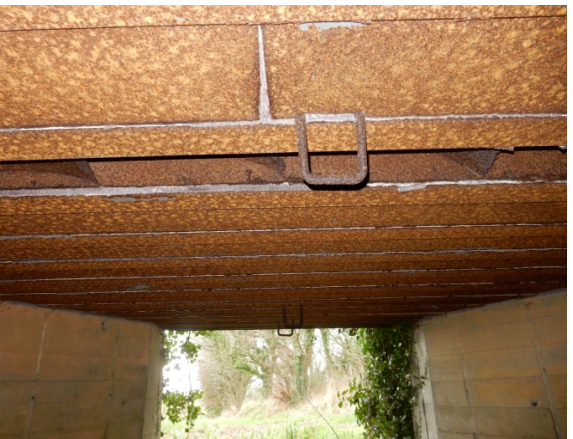

(c)

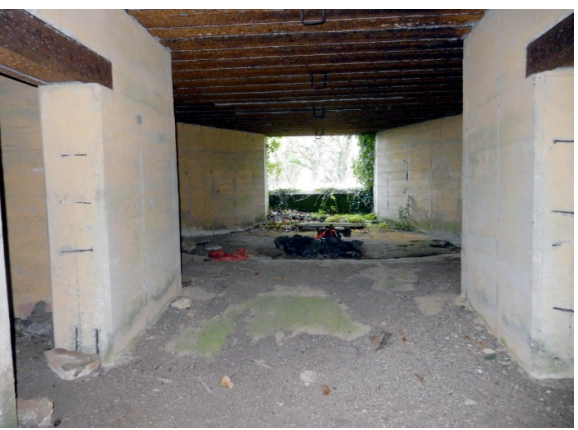

(b)

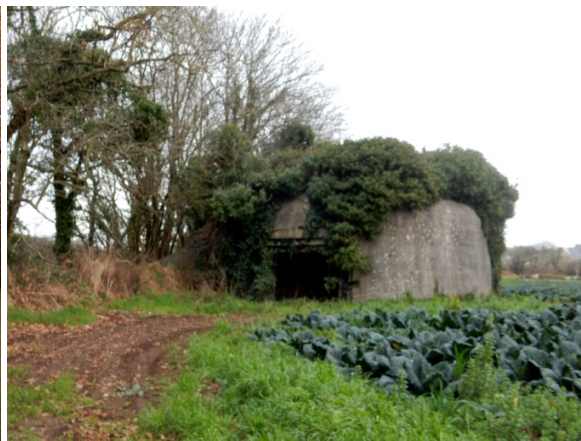

(d)

Figure 15. Stp $\operatorname{Re} 77-R 669$ (2): (a) Fire room rear side aperture covered by vegetation; (b) Fire room, on the left side, entrance of the combat gas extraction system room, on the right side entrance of the of the ammunition room; (c) Fire room, metallic ceiling with two gun lifting joints and gate of the combat gas extraction system; (d) Fire room front side aperture with splinter guards. 
A $V f(16)$ bunker (Figure 16), about $6 \times 6 \mathrm{~m}$, similar to $V f(5)$ and $V f(7)$ was completely buried in the terrain. The entrance was not provided with protection walls and emerged partially from the terrain, allowing to seen a well preserved, white painted, internal room. On one of its wall an entrance to a nearby room was visible. Although the apparent absence on its coverage of chimney conduits, its position close to the road Plumoguer Blanc Sablons, suggested for this Vf the function of guardhouses for a group of soldiers in charge of the surveillance of said road (Figure 11). The emerging $V f(16)$ concrete structure was in a good preservation state without damages due to bombardments or combats.

A $V f(10)\left(48^{\circ} 23^{\prime} 51.05^{\prime \prime} \mathrm{N}, 04^{\circ} 43^{\prime} 52.42^{\prime \prime} \mathrm{W}, 51.18 \mathrm{~m}\right.$ ) (Figure 17, Figures 18 (a)-(b)), about $5 \times 5 \mathrm{~m}$, similar to $V f(5)$. It was completely buried in the terrain. The entrance, partially emerging from the terrain, allowing inspecting the interior formed by a short corridor and an internal room both preserving their original white painting. Although the apparent absence on its coverage of chimney conduits, its position close to the road Plumoguer-Blanc Sablons, suggested for this $V f$ the function of guardhouses for a group of soldiers in charge of the surveillance of said road (Figure 11). The emerging $V f(10)$ concrete structure was in a good preservation state without damages due to bombardments or combats.

A $V f(8)\left(48^{\circ} 23^{\prime} 51.63^{\prime \prime N}, 04^{\circ} 43^{\prime} 54.64^{\prime \prime} \mathrm{W}, 51.76 \mathrm{~m}\right)$ (Figure $18(\mathrm{c})-(\mathrm{d})$ ), about 5 $\times 5 \mathrm{~m}$, similar to $V f(5)$ completely buried in the terrain. Its position, about $20 \mathrm{~m}$ from the $R 669$ (3), suggested that it was intended for storing ammunition and/or materials for the $R 669$ (3). The emerging Vf (80) concrete structure

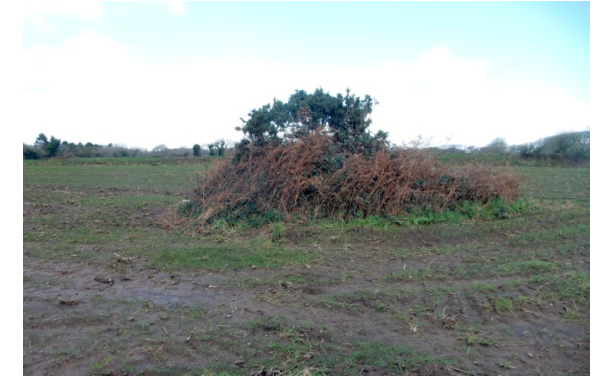

(a)

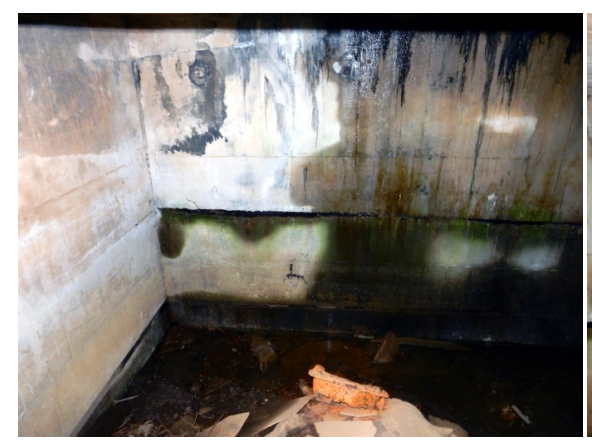

(c)

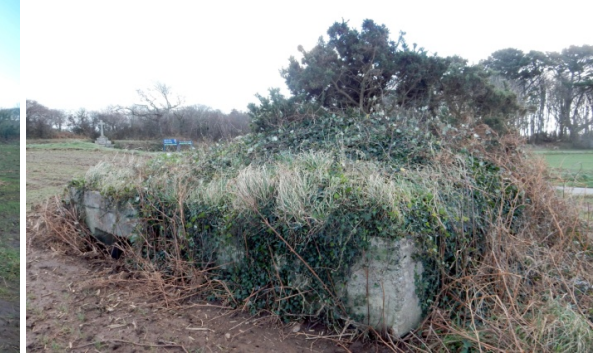

(b)

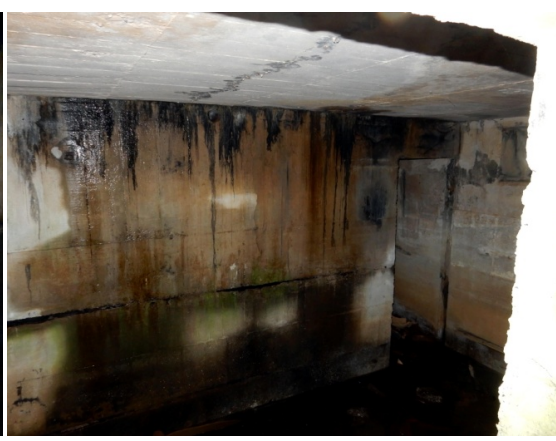

(d)

Figure 16. Stp Re 77-Vf (16): (a) Rear side; (b) Front side with entrance; (c) Internal room; (d) Internal room, on the right entrance to a nearby room. 


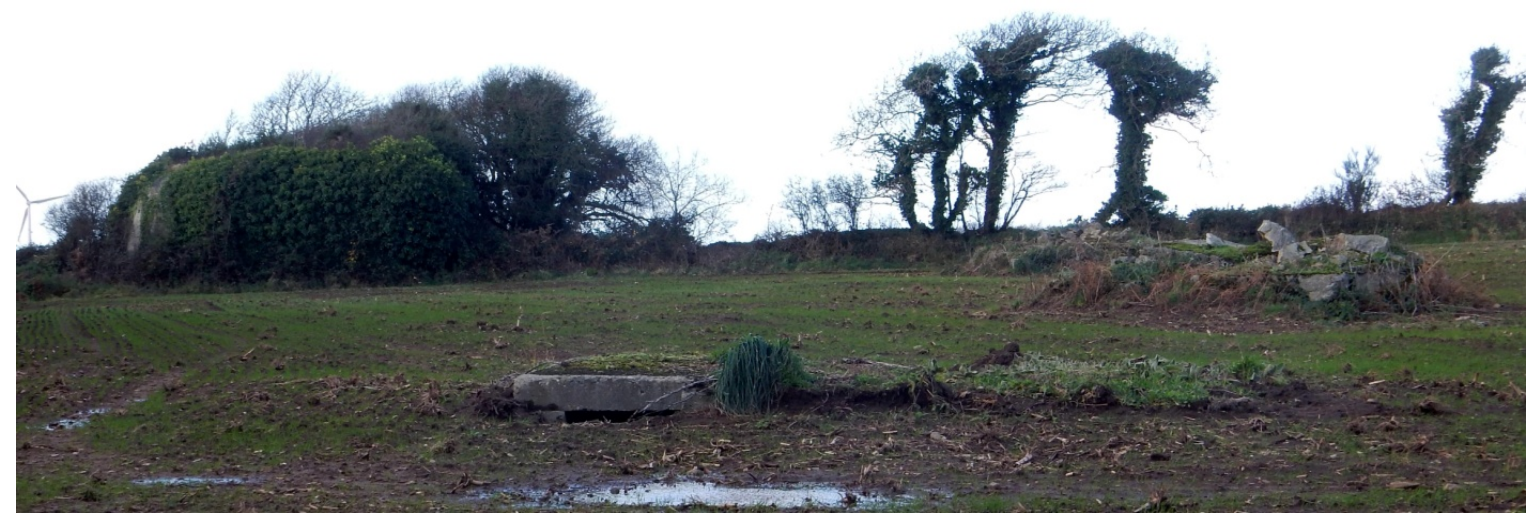

Figure 17. Stp $\operatorname{Re} 77: \operatorname{Vf}(10), \operatorname{Vf}(8), \operatorname{Vf}(9)$, on the left, in the foreground $R 669$ (4).

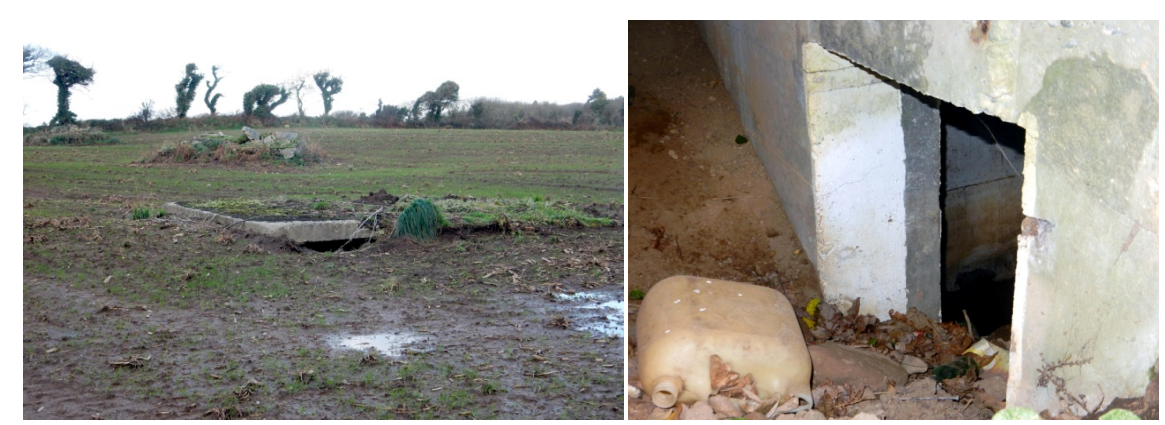

(a)

(b)

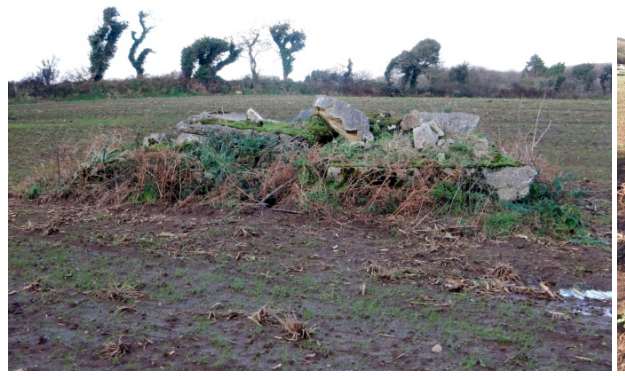

(c)

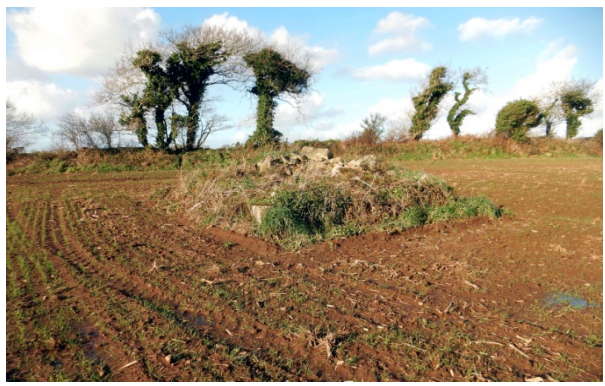

(e)

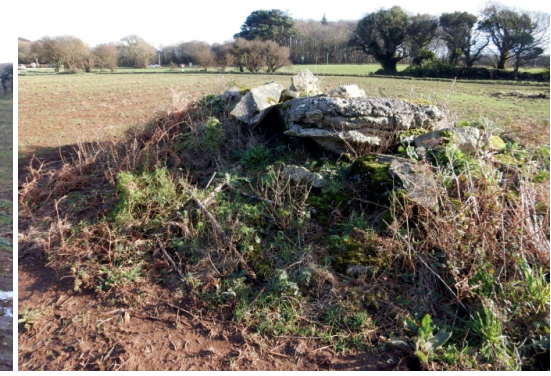

(d)

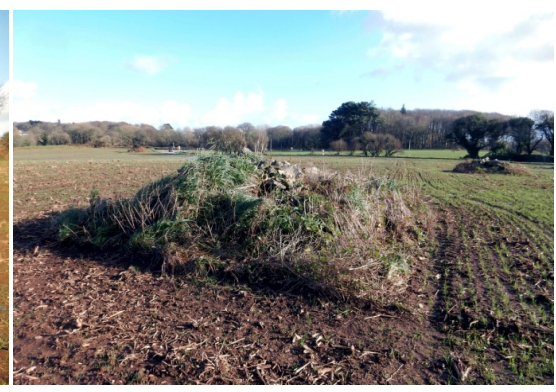

(f)

Figure 18. Stp Re 77: (a) Vf(10) external structure with partially obstructed entrance; (b) $V f(10)$ corridor and internal room, (c)-(d) $V f(8)$ damaged external structure; (e)-(f) $V f$ (9) damaged external structure. 
appeared rather damaged, suggesting that $V f(8)$ was intentionally dynamited or that stones or concrete slabs dispersed in the cultivated fields were collected on its coverage.

A $V f(9)\left(48^{\circ} 23^{\prime} 52.45^{\prime \prime} \mathrm{N}, 04^{\circ} 43^{\prime} 55.7^{\prime \prime} \mathrm{W}, 52.48 \mathrm{~m}\right)$ (Figures $18(\mathrm{e})$-(f)), about 5 $\times 5 \mathrm{~m}$, similar to $V f(5)$ and $V f(8)$ completely buried in the terrain. Its position, about $30 \mathrm{~m}$ from the $R 669$ (4), suggested that it was intended for storing ammunition and/or materials for the $R 669$ (4). The emerging $V f(9)$ concrete structure appeared rather damaged, suggesting that the $V f(9)$ was too intentionally dynamited or that stones or concrete slabs dispersed in the cultivated fields were collected on its coverage.

An $R 669$ (3) $\left(48^{\circ} 23^{\prime} 50.52^{\prime \prime} \mathrm{N}, 04^{\circ} 43^{\prime} 55.29^{\prime \prime} \mathrm{W}, 50.4 \mathrm{~m}\right.$ ) (Figure 19) for $150 \mathrm{~mm}$ gun. Its concrete structure was covered by vegetation, but apparently without damages due to bombardments or combats. The rear aperture introduced into an empty fire room, deprived of its original furniture. The walls preserved the original white painting and the vertical wood insulation supports embedded in the concrete. On the walls, no traces of a thermal insulation. On the floor, the square carriage wheel gun emplacement and the gun carrier legs emplacement were well recognizable. The metallic ceiling preserved two joints for the gun lifting and the gates of the combat gas extraction system, preserving portions of their original grids. The ammunition room was empty and the combat gas extraction system room preserved some rusted portion of conduits. The exhausted combat gas pipe and a possible niche hosting it, on the $R 699$ (3) rear side, were covered by vegetation and not visible.

An $R 669$ (4) (48 $23^{\prime} 51.79^{\prime \prime} \mathrm{N}, 04^{\circ} 43^{\prime} 57.26^{\prime \prime} \mathrm{W}, 51.79 \mathrm{~m}$ ) (Figure 20) for $150 \mathrm{~mm}$ gun. Its concrete structure was completely covered by vegetation, but apparently

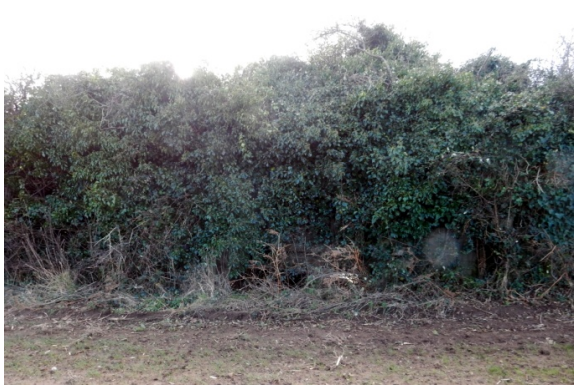

(a)

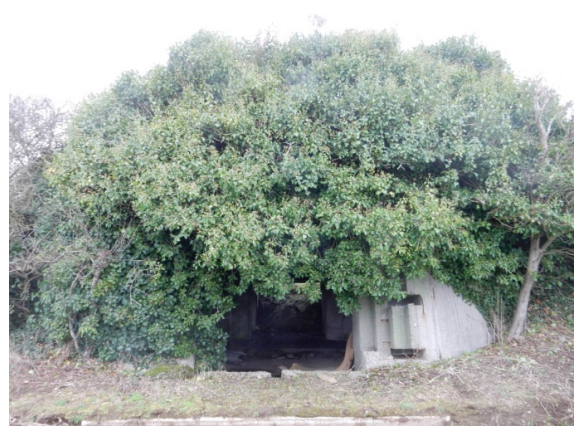

(c)

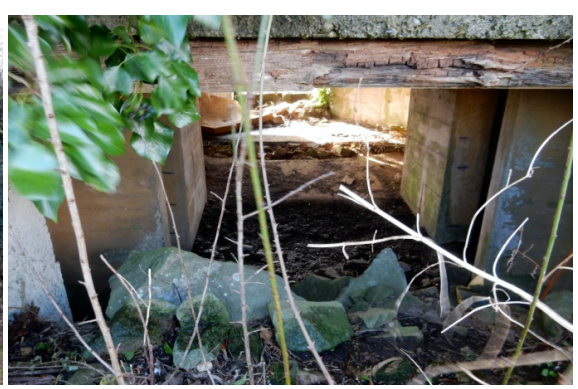

(b)

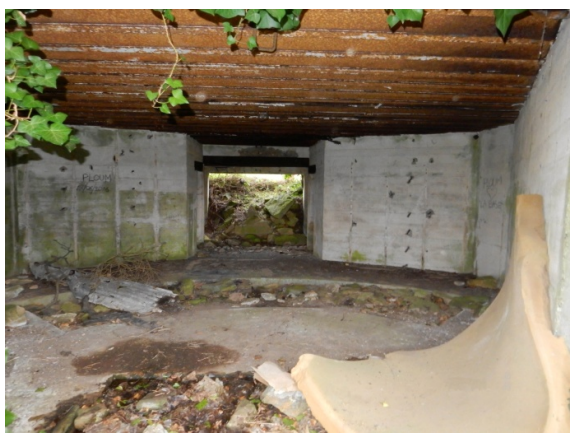

(d) 


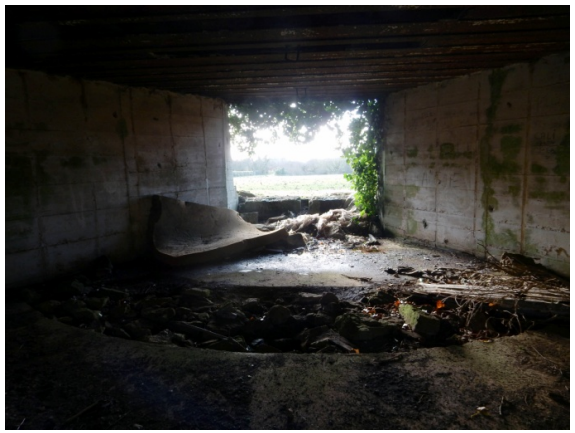

(e)

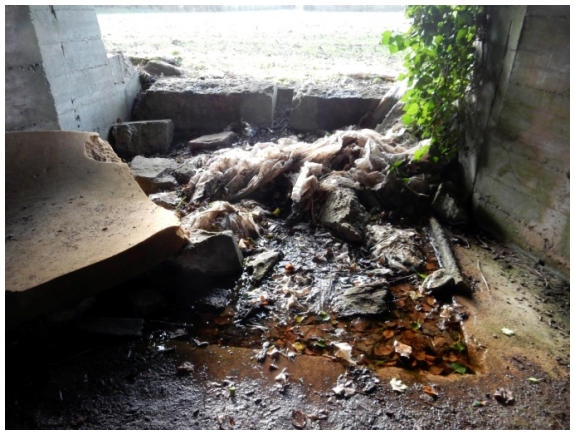

(f)

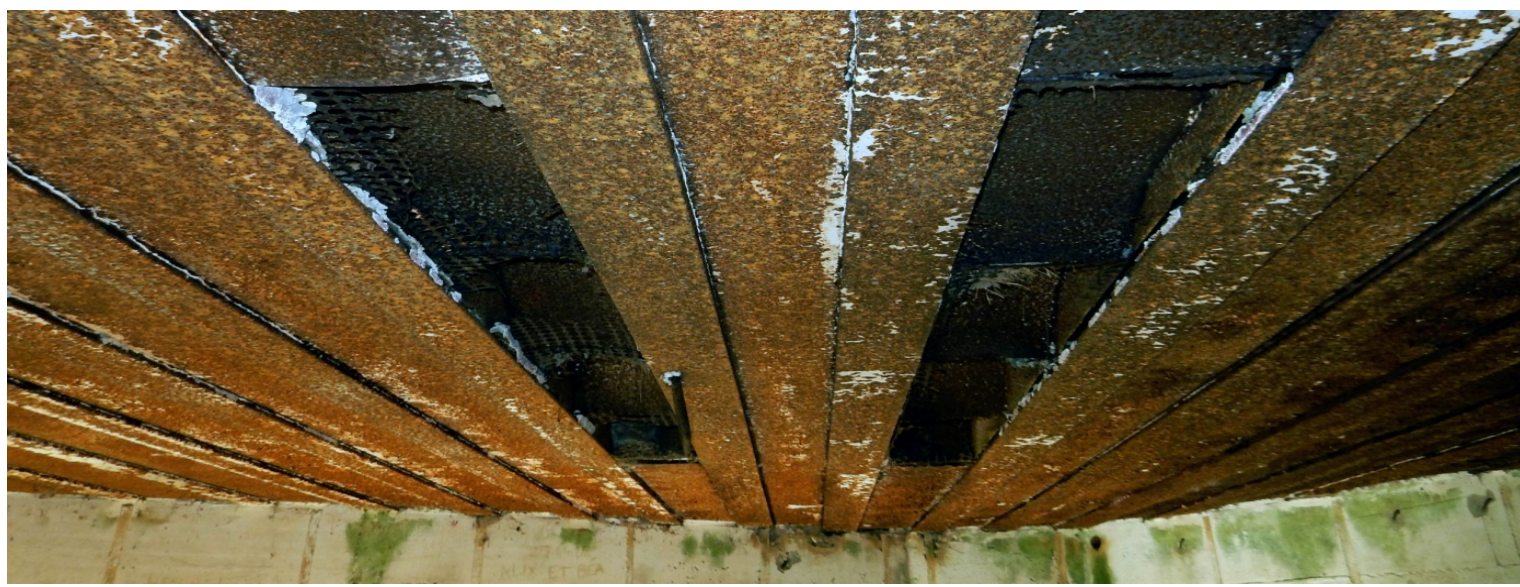

(g)

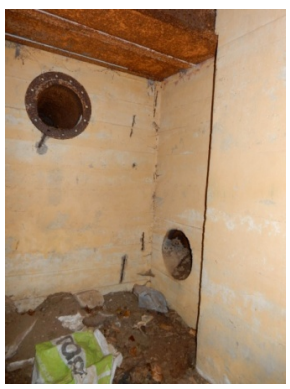

(h)

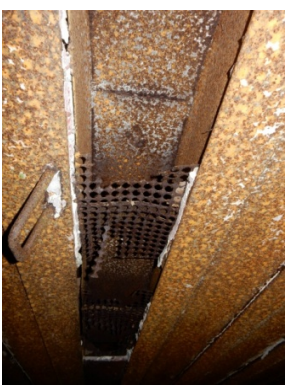

(i)

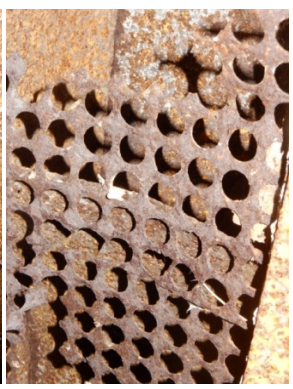

(j)

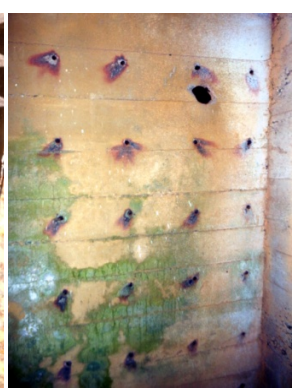

(k)

Figure 19. $R 669$ (3): (a) Fire room rear side aperture covered by vegetation; (b) Fire room seen from the rear side aperture; (c) Fire room front side aperture with splinter guards covered by vegetation; (d) Fire room, rear side aperture, square carriage wheel gun emplacement and arcuate gun carrier legs emplacement; (e) Square carriage wheel gun emplacement; (f) Square carriage wheel gun emplacement; (g) Fire room, metallic ceiling with gates of the combat gas extraction system; (h) Combat gas extraction system room; (i) Fire room, metallic ceiling with gun lifting joint and gates of the combat gas extraction system; (j) Grid of a gate of the combat gas extraction system; (k) Fire room rear side aperture, holes in the concrete wall.

without damages due to bombardments or combats. The rear aperture introduced into an empty fire room, deprived of its original furniture. The walls preserved the original white painting and the vertical wood insulation supports embedded in the concrete. On the walls, no traces of a thermal insulation system. 


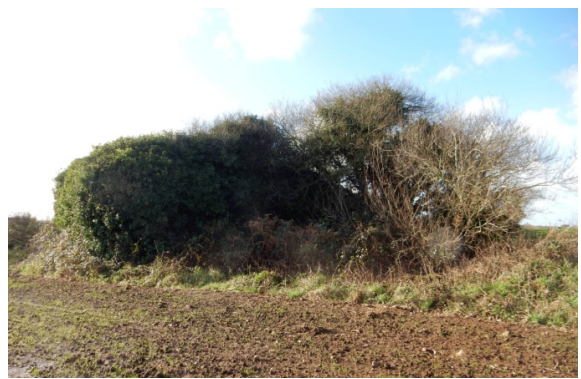

(a)

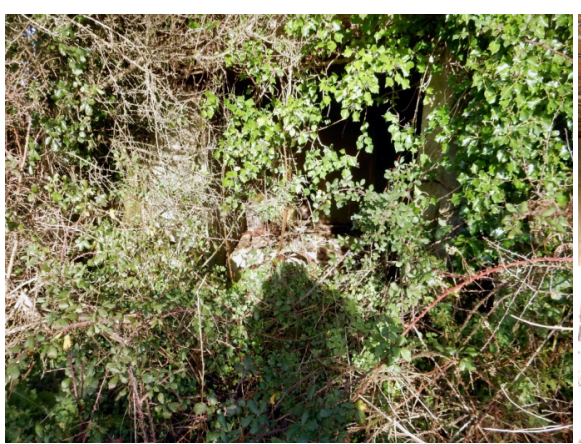

(c)

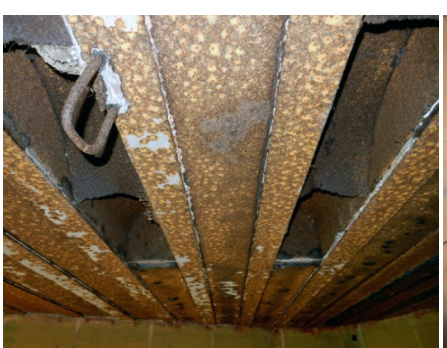

(e)

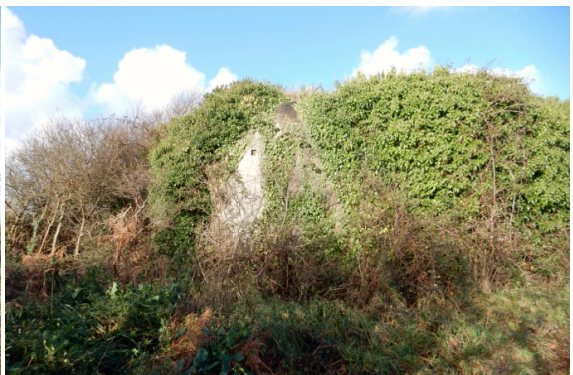

(b)

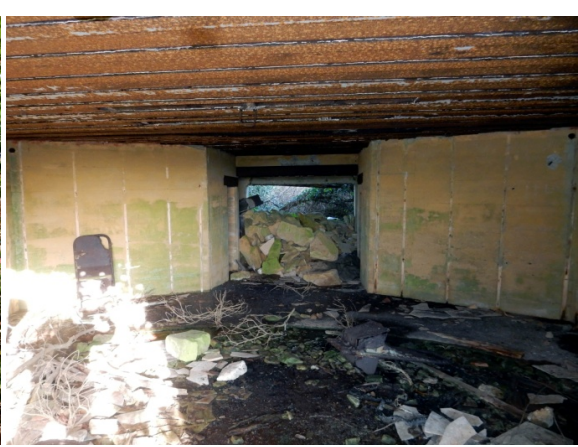

(d)

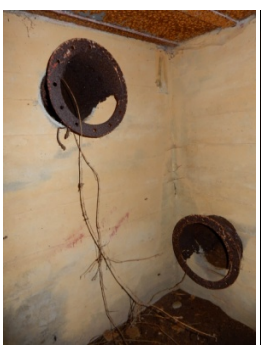

(f)

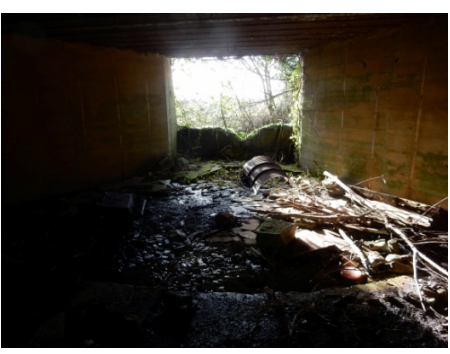

(g)

Figure 20. Stp Re 77-R 669 (4): (a)-(b) External structure covered by vegetation; (c) Fire room front side aperture covered by vegetation; (d) Fire room, rear side aperture and arcuate gun carrier legs emplacement; (e) Fire room, metallic ceiling with gates of the combat gas extraction system and gun lifting joint; (f) Combat gas extraction system room; (g) Fire room, front side aperture and arcuate gun carrier legs emplacement.

On the floor, the square carriage wheel gun emplacement and the arcuate gun carrier legs emplacement, although both covered by terrain, were well recognizable. The metallic ceiling preserved two joints for the gun lifting and the gates of the combat gas extraction system, deprived of their original grids. The ammunition room was empty and the combat gas extraction system room preserved some rusted portion of conduits. The exhausted combat gas pipe and a possible niche hosting it, on the $R 699$ (4) rear side, were covered by vegetation and not visible.

The search on the terrain for rests of other constructions like ammunition bunkers, storage bunkers, anti-aircraft guns bunkers, lodging barracks provided no result. The search on the terrain for a metallic barrier, barbed wires and the mine fields encircling the Stp Re 77 (Figure 11) provided no results. 


\section{Stp Re 79}

The Stp Re 79, about $3 \mathrm{~km}$ from Ploumoguer, comprised a heavy artillery battery probably intended to be formed, as Stp Re 77 and Stp Re 80, by four $R 669$. However only one $R 669$ and several $V f$ were completed at the time of the Battle of Brittany (Figures 21-23). Nowadays, they are located on a private terrain, on one side of the Ploumoguer-Plougonvelin road (Rapport Pinczon du Sel, 1947-1948). The proprietor allowed the visit but not to enter the site, for avoiding disturbances to his bred horses and goats. The visit took place on 27th December 2017. The Stp Re 79 identified components were the following.

A $V f(7)\left(48^{\circ} 22^{\prime} 43.42^{\prime \prime} \mathrm{N}, 04^{\circ} 42^{\prime} 34.12^{\prime \prime} \mathrm{W}, 55.04 \mathrm{~m}\right)$ (Figure $22(\mathrm{a})$ ), about $3 \times 5$ $m$ completely buried in the terrain, at the entrance of the site. Only a portion of its coverage emerged from the terrain. The entrance was buried in the terrain; so that the inspection of the interior was not possible. The apparent absence on its coverage of chimney conduits suggested that it was intended for storing ammunitions and/or materials, although the function of guardhouse for a group of soldiers, at the one entrance of the Stp, cannot be excluded. The emerging portion of $V f(7)$ concrete structure was in a good preservation state without damages due to bombardments or combats.

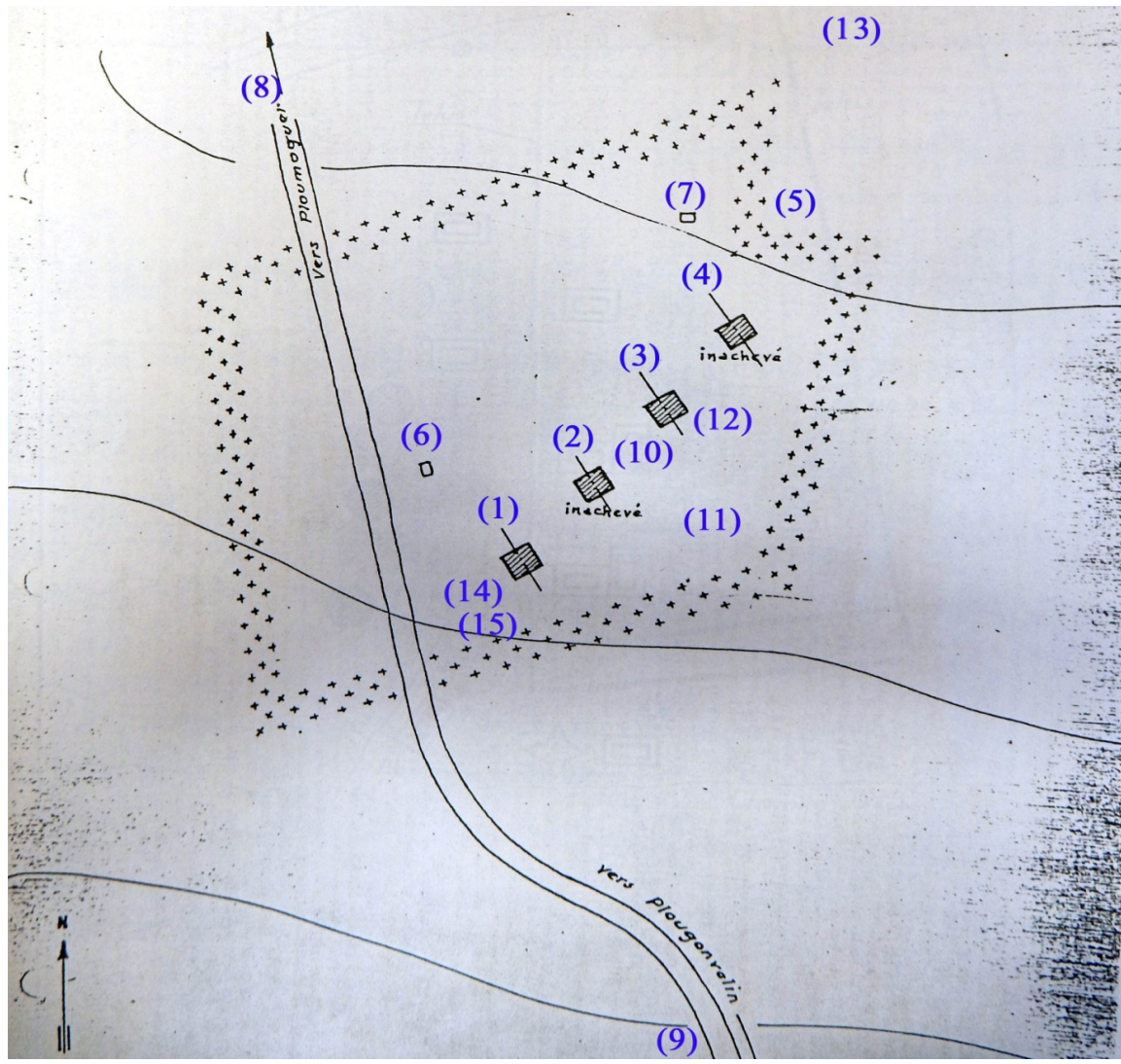

Figure 21. Stp Re 79: (1) $R 669$ emplacement; (2) $R 669$ emplacement; (3) $R$ 669; (4) $R$ 669 emplacement; (5) barriers and mine fields; (6) possible $V f$; (7) Vf, (8) road to Ploumoguer; (9) Road to Plougonvelin; (10) Vf, (11) Vf, (12) Possible $V f$ isolated in a field (Rapport Pinczon du Sel, 1947-1948, Plan_no. 117-IV). 


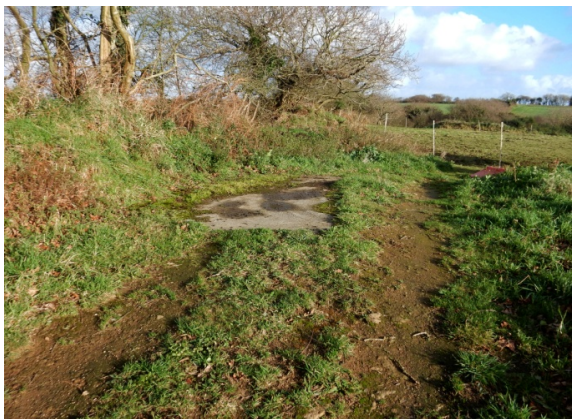

(a)

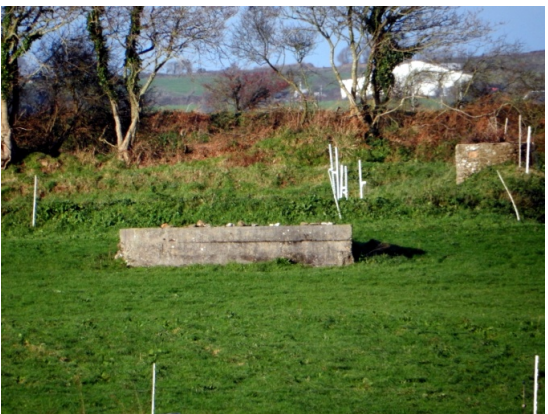

(c)

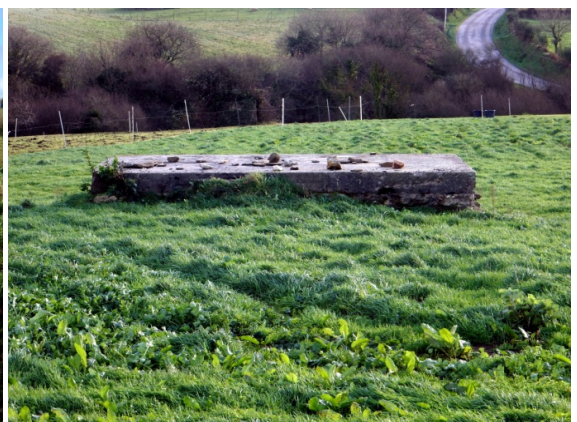

(b)

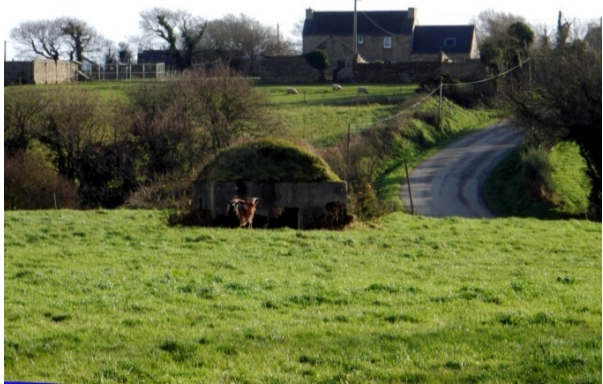

(d)

Figure 22. Stp $\operatorname{Re} 79$. (a) $V f(7)$, coverage partially emerged from the terrain; (b) $V f(10)$ front side; (c) $V f(10)$ rear side; (d) $V f(11)$.

A $V f(10)\left(48^{\circ} 22^{\prime} 41.38^{\prime \prime} \mathrm{N}, 04^{\circ} 42^{\prime} 33.91^{\prime \prime} \mathrm{W}, 53.17 \mathrm{~m}\right)$ (Figures $22(\mathrm{~b})-(\mathrm{c})$ ), about $3 \times 5 \mathrm{~m}$, similar to $V f(7)$ emerged about $0.5 \mathrm{~m}$ from the terrain. The apparent absence on its coverage of chimney conduits and its position, about $10 \mathrm{~m}$ from the $R 669$ (3), suggested that it was intended for storing ammunition and/or materials for the $R 669$ (3) rather than hosting a group of soldiers. The emerging $V f(10)$ concrete structure was in a good preservation state without damages due to bombardments or combats.

A $V f(11)\left(48^{\circ} 22^{\prime} 39.13^{\prime \prime} \mathrm{N}, 04^{\circ} 42^{\prime} 33.02^{\prime \prime} \mathrm{W}, 50.48 \mathrm{~m}\right)$ (Figure 22(d)), about $4 \times$ $4 \mathrm{~m}$, similar to $V f(7)$ emerged about $2 \mathrm{~m}$ from the terrain. The interior appeared formed by a single square room with one North side entrance aligned with a South side entrance. A monticule of terrain protected its coverage. Its position, near the site South border and the protected coverage suggested that it was intended for hosting a group of soldiers in charge of the surveillance of the South side of the site. The emerging $V f(11)$ concrete structure was in a good preservation state without damages due to bombardments or combats.

A $V f(12)\left(48^{\circ} 22^{\prime} 42.11^{\prime \prime} \mathrm{N}, 04^{\circ} 42^{\prime} 32.72^{\prime \prime} \mathrm{W}, 52.69 \mathrm{~m}\right)$ (Figure 21), about $3 \times 5$ $\mathrm{m}$, similar to the $V f(7)$ emerged about $0.5 \mathrm{~m}$ from the terrain. The apparent absence on its coverage of chimney conduits and its position, about $10 \mathrm{~m}$ from the $R 669$ (3), suggested that it was intended for storing ammunition and/or materials for the $R 669$ (3) rather than hosting a group of soldiers. The emerging $V f$ (12) concrete structure was in a good preservation state without damages due to bombardments or combats. 
A $V f(14)\left(48^{\circ} 22^{\prime} 40.14^{\prime \prime} \mathrm{N}, 04^{\circ} 42^{\prime} 35.85^{\prime \prime} \mathrm{W}, 52.76 \mathrm{~m}\right.$ ) (Figure 21 ), about $3 \times 5$ $\mathrm{m}$, similar to the $V f(7)$ was visible on the terrain. The apparent absence on its coverage of chimney conduits suggested that it was intended for storing ammunitions and/or materials.

A $V f(15)\left(48^{\circ} 22^{\prime} 39.50^{\prime \prime} \mathrm{N}, 04^{\circ} 42^{\prime} 35.46^{\prime \prime} \mathrm{W}, 52.43 \mathrm{~m}\right.$ ) (Figure 21$)$, about $2 \times 2$ $\mathrm{m}$, was visible on the terrain. Its purpose remains unknown.

A $R 669$ (3) $\left(48^{\circ} 22^{\prime} 41.80^{\prime \prime} \mathrm{N}, 04^{\circ} 42^{\prime} 33.24^{\prime \prime} \mathrm{W}, 53.06 \mathrm{~m}\right.$ ) (Figure 23) for $150 \mathrm{~mm}$ gun. Its concrete structure appeared in a good preservation state without damages due to bombardments or combats. A modern agricultural shed was added to one side of the $R 669$ (3). The fire room front aperture was closed by a modern white door provided with two rectangular windows. The fire room rear aperture was open allowing seeing a portion of the fire room interior and the entrance of the combat gas extraction system room. The walls appeared to preserve the original white painting. The exhausted combat gas pipe, without hosting niche, was visible on the $R 699$ (3) rear side.

No construction traces were visible at the $R 669$ (1), $R 669$ (2) and $R 669$ (4) emplacements.

On the terrain no ruins of constructions like anti-aircraft guns bunkers, lodging barracks, metallic barriers, barbed wires and mine fields encircling the Stp $\operatorname{Re} 79$ (Figure 21) were visible.

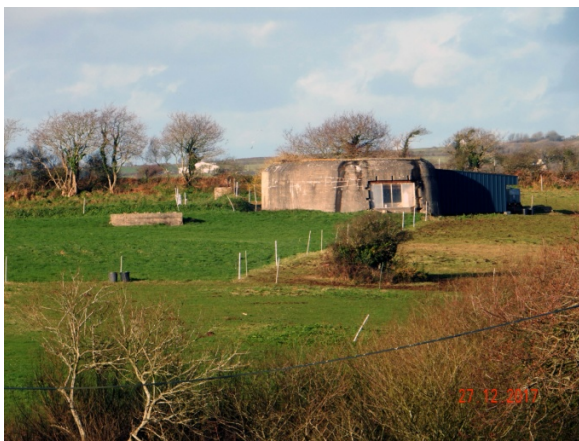

(a)

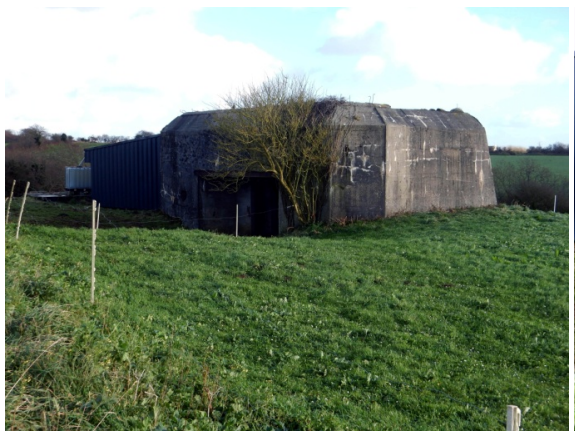

(c)

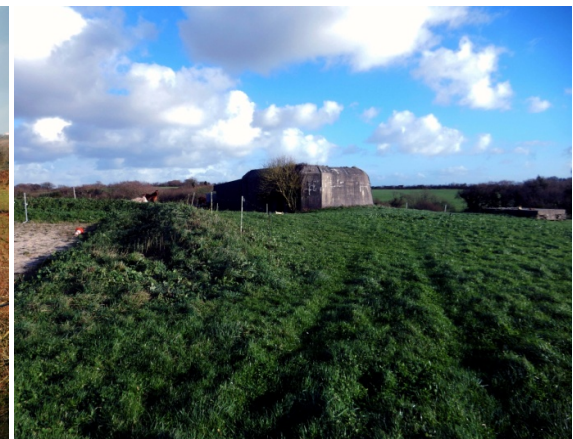

(b)

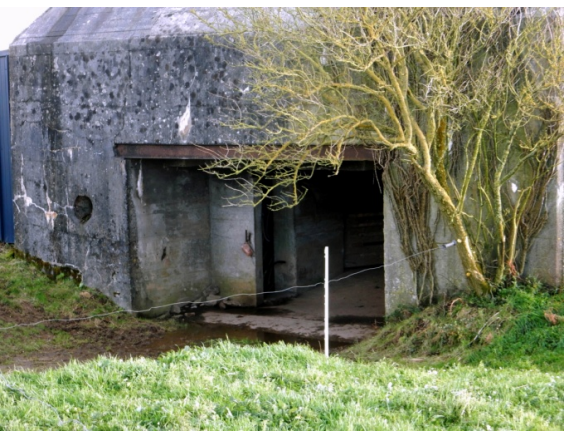

(d)

Figure 23. Stp Re 79. (a) $R 669$ (3) front side, on the left $V f($ ); (b) $R 669$ (3) rear side; (c) $R 669$ (3) rear side, on the left modern agricultural shed; (d) $R 669$ (3), fire room rear aperture with entrance of the combat gas extraction system room, on the left exhausted combat gas pipe. 


\section{Discussion}

The Stp Re 77, Re 79 and Re 80 encircled Ploumoguer suggesting that in Ploumoguer were located not only the the Stp Re 311-FuMB 445 Donau coordination centre (Blanchard, 2017), but also their Headquarter (Kommandantur) as well as possible further support and lodgment structures. The absence of a fire direction bunker, like the $R$ 120a at Pointe de la Varde (Stp Ra 109) (Tomezzoli \& Pottier, 2016), both in Ploumoguer and in the surroundings, let to suppose that the Kommandantur directed the fire of its Stps on the basis of information and data received from elsewhere.

The Stp fire ranges were not radially oriented with respect to Ploumoguer, suggesting that it was not the primary objective to be defended. The fire ranges of Stp Re 77 and Re 80 were directed respectively toward the beaches of Blanc Sablons and Le Conquet, both north to the Point Saint-Mathieu. The fire range of Stp Re 79 was directed toward the beaches of the Anse de Bertheaume, south to the Pointe Saint-Mathieu, at the entrance of the military port of Brest. Therefore, the Stps constituted a remote defense support system for enhancing the fire of the defense structures already in place around said beaches for contrasting possible allied landings.

The Stp Re 77, Re 79 and Stp Re 80 conformed to the German heavy artillery batteries general design of the WW II already observed at the Kullack heavy artillery battery $\left(48^{\circ} 39^{\prime} 59.9^{\prime \prime} \mathrm{N}, 1^{\circ} 55^{\prime} 31.0^{\prime \prime} \mathrm{W}\right)$ near Saint Coulomb, at Les Ormeaux (Tomezzoli \& Pottier, 2016) and Stp Re 305 Von Holtzendorf, all consisting of four aligned $R 669$ or special constructions (SK-Sonderkonstruktion) bunkers (Tomezzoli, 2015) with annexed Vf bunkers. The absence of Flak batteries for the defense of the Stps is surprising, unless that the anti-aircraft defense were assured by the Flak batteries around Brest (Tomezzoli \& Dupont, 2009).

The inspections of the R669s of the Stps around Ploumoguer as well as those visited in the past permit to correct a recurrent mistake in literature (Rudi, 1998) and on the web, according to which the two rooms (4) near the fire room (Figure $7(\mathrm{j})$ ) of an $R 669$ were ammunition rooms for storing separately respectively cases and shells for security reasons. It appears now clear that one of said two rooms (the left one, Figure $7(j)$ ) was actually a combat gas extraction system room in which a pump, electrical or manual, extracted, through gates in the ceiling of the fire room, the combat gas produced by the gun fire, and discharged it outside the $R 669$ through an exhausted combat gas pipe. The shells were stored in the other R 669 room (4) and/or in a Vfnear the $R 669$.

The Stp Re 80 had four $R 669$ s operative at the moment of the battle of Brittany. A French air reconnaissance image of 1948 (C3639-0421_1948-MISSION BRETAGNE_022, n 227, Échelle 1/24434, Argentique, 16/04/1948) reveals no rests of other bunkers or barracks. Therefore, the personnel and materials were probably hosted in the nearby manor of Cohars or in Ploumoguer (Figure 1). The same image confirms that the trench hosting the $R 669 \mathrm{~s}$ was from origin. The battery combat operations are unknown. 
The Stp Re 77 had four $R 669$ operative at the moment of the battle of Brittany. The personnel and materials were probably hosted in disappeared barracks in the site or in Ploumoguer. Notwithstanding the absence of rests of cable lines, electrical switches, lamps and chimney conduits, the central position of $V f(6)$ suggests that it hosted a relay command for directing the fire of Stp Re 77. Although no rests of radio and telephonic devices were remarked, $V f(6)$ was probably able to direct the fire of $R e 77$ through communication equipment hosted in its corridor rectangular niches. The battery combat operations are unknown.

The Stp Re 79 had only one $R 669$ operative at the moment of the battle of Brittany. However, it is possible that a gun was present in a non-protected or semi-protected position, in each $R 669$ emplacement. The gun in $R 669$ (3) was protected against air and field attacks but its fire range was limited to the direction of Anse de Bertheaume for its defense or bombardment. The guns in $R 669$ emplacements (1), (2) and (4) were exposed to air and field attacks but their fire range was unrestricted. The personnel and materials were probably hosted in disappeared barracks. The battery combat operations are unknown.

The passive recognition of foe radar emissions at FuMB 445 was probably ensured by a device Fu.M.B. 21/27, which consisted of the receptors FuMB 21 "Pellworn" covering a waveband of $136-850 \mathrm{MHz}(2.20 \mathrm{~m}-35 \mathrm{~cm})$ and a FuMB 27 "Chinesen" covering a waveband of $2500-3750 \mathrm{MHz}(12 \mathrm{~cm}-8 \mathrm{~cm}) \mathrm{com}$ prising a large parabolic antenna, a small parabolic antenna and a four dipoles antenna. The instrumentation and the operators were hosted in a cabin similar to those of the radars Freya and Seetakt (Blanchard, 2017). The $V 256$ was conceived for hosting an electrical generator for a searchlight G 200. However, its presence at FuMB 445 is not surprising. In fact, its interior was well adapted to the needs of the Fu.M.B. 21/27. Its machine room hosted an electrical generator adapted for supply power to the Fu.M.B. 21/27, its fuel depot room stored fuel for the generator and, its lodgment room hosted an officer and 5 radar operators. The $V 256$ was a Class B construction, i.e. with walls up to $2 \mathrm{~m}$ thick, and consisted of $560 \mathrm{~m}^{3}$ of reinforced concrete, $28.5 \mathrm{t}$. of round steel and $9.5 \mathrm{t}$ of formed steel. The Fu.M.B. 21/27, as the searchlight $G 200$ was powered by a mobile cable up to $100 \mathrm{~m}$ long (BAMA, 1944). The absence of the rests of a concrete splitter wall or ground protection wall (Figures 8-9) let suppose that the Fu.M.B. $21 / 27$ was placed on the bunker coverage or on the nearby terrain without protection. The presence at $F u M B 445$ of a radar for directing the fires of the batteries around Ploumoguer is not confirmed. Possible further Fu.M.B. 445 personnel and materials were probably hosted in the nearby Kervélédan farm. The presence of a cylindrical water pit of German construction near the $V 256$ proved that the problem of lack of drink and kitchen water at FuMB 445 mentioned above (Floch, 2012) was definitively solved.

\section{Conclusion}

The role of the witnesses, here indirect witnesses sometime proprietors of the vi- 
sited sites, were already remarked in some previous publications, aided a lot also in this case for identifying and exploring the Stps components and so to complete the frame of the WWII German defense structures around Ploumoguer. Now that said frame is clear it is hoped that it will stimulate further researches about the WWII German presence in the sector of Ploumoguer and in general about the German military structures of the Atlantic Wall.

\section{Acknowledgements}

I wish to thank very much all the proprietors of the visited sites for their kind permission of visiting them, the proprietor of the farm near Kérigoarn-Kerizauen for his indications about FuMB 445 site, the proprietor of the farm near Penhars for his information about a possible German transmission center, the Service Historique de la Defence in Brest (FR) for the permission of using in this article the Plans_no. 114-117-IV of the Rapport Pinczon du Sel, 1947-1948, the Bundesarchiv-Militärarchiv (BAMA) in Freiburg (DE) for the permission of using in this article the $V 256$ plan (BAMA, 1944) and Mr. B. Haas for his researches in the Bundesarchiv-Militärarchiv (BAMA) concerning the WWII German defenses structures around Ploumoguer.

\section{References}

BAMA (1944). Regelbauten der Kriegsmarine.

Blanchard, Y. (2017). La Station Wolga du Menez Hom.

Dupont, Ph., Fresil, Y., \& Tomezzoli, G. (2007). Deutsche Militärbauten bei Rennes, DAWA Nachrichten, Ausgabe 49 (pp. 56-66). Köln: Verlag Harry Lippmann.

Floch, A. (2012). L'Occupation Allemande dans les 162 Communes du Nord-Finistere (pp. 298-301). Saint Thonan: CLOITRE imprimeurs.

Lippmann, H. (2016). Deutsche Atlantikwall Archiv. Bretagne West mit Brest. Stand 17. http://www.atlantikwall.info/radar/france/rf_.htm\#Bretagne_West

Rapport Pinczon du Sel (1947-1948). Le Mur de l'Atlantique la Cote de la Manche et de l'Atlantique du Mont Saint-Michel a Laita. Brest: Service Historique de la Marine.

Rudi, R. (1998). Typologie du Mur de l'Atlantique. Beetsterwaag.

Tomezzoli, G. (2015). The Kieswerk of Pointe Saint-Mathieu and the Atlantic Wall. Advances in Anthropology, 5, 177-182. https://doi.org/10.4236/aa.2015.54017

Tomezzoli, G. T. (2017a). The WWII German Heavy Artillery Battery AV 67 of Cleus Foz (Finistère-FR). Archaeological Discovery, 5, 61-78.

https://doi.org/10.4236/ad.2017.52004

Tomezzoli, G. T. (2017b). The WW II German Coastal Artillery Battery H.K.B. 1274/StP C 342 at Camaret sur Mer (Finistère-FR). Archaeological Discovery, 5, 116-141. https://doi.org/10.4236/ad.2017.53008

Tomezzoli, G. T. (2017c). The WW II German Stutzpunkt on the Menez-Hom (Finistere-FR). Archaeological Discovery, 5, 224-237. https://doi.org/10.4236/ad.2017.54013

Tomezzoli, G. T., \& Pottier, L. L. (2016). Journey through the Defenses of the Festung Saint-Malo (FR)-1. Archaeological Discovery, 4, 125-142. https://doi.org/10.4236/ad.2016.44010

Tomezzoli, G., \& Dupont, Ph. (2009). Die Flak Batterien der Festung Brest, DAWA Nachrichten, Ausgabe 54 (pp. 4-43). Köln: Verlag Harry Lippmann. 